\title{
Is Public Debt Harmful Towards Economic Growth? New Evidence from Sri Lanka
}

\author{
Thilak Ranjeewa Priyadarshana ${ }^{1}$
}

\begin{abstract}
This study examines the impact of public debt on economic growth and investment in Sri Lanka during the period from 1977 to 2017. The two model specifications, growth model and investment model, are estimated using the Johansen Cointegration technique and the Vector Error Correction Model (VECM) specified under the Vector Auto Regressive (VAR) framework using annual data for the period of 1977-2017. The results of the two models reveal that public debt, which consists of foreign debt and domestic debt, has a significant and positive impact on economic growth and investment in the long run. In the short run, a significant association between public domestic debt and economic growth as well as total public debt and investment is observed, suggesting mixed results. Debt service payments in the long run show a significant negative effect on both economic growth and investment, reflecting a crowding out investment. The finding suggests that using government debt for priority investment expenditures with a prudent debt management strategy to curtail the impact of crowding out investment will have a favourable impact on economic growth of the country, particularly in the long run.
\end{abstract}

Key Words: Public debt, economic growth, vector error correction, Sri Lanka.

JEL Classification: H63; O40; C50

${ }^{1}$ The author is currently serving as a Senior Economist of the Economic Research Department. Corresponding email: priyadarshana@cbsl.lk. The author wishes to thank the anonymous reviewers for their comments and advice. The views presented in this paper are those of the author and do not necessarily indicate the views of the Central Bank of Sri Lanka. 


\section{Introduction}

The impact of public debt ${ }^{2}$ on economic growth is a controversial and debated issue in many countries, particularly in developing economies (Deshappriya 2012). In literature, there is no consensus as to whether public debt affects economic growth positively or negatively (Mhlaba 2017). However, academic opinion on the impact of public debt on economic growth can be divided into three stands (Munir 2015; Oleksandr 2003). The first stand is that there is a positive association between public debt and economic growth. This implies that public debt stimulates economic growth through investments in infrastructure, education, health, social welfare and other development activities (eg., Kobayashi 2015; Nantwi 2016; Wibowo 2017). The second stand suggests a negative correlation between public debt and economic growth (eg., Atique 2012; Mhlaba 2017; Akram 2016). On the negative front, higher accumulation of public debt adversely affect on economic growth as described by the "debt overhang" effect, "crowding out" effect and "uncertainty" effect. Debt overhang effect asserts that if the country's accumulated debt stock is larger than its repayment ability in the future, the expected debt service cost will increase hindering further investments. The crowding out effect implies that higher accumulated foreign debt and resulted debt servicing costs lead to crowd out expenditure on public investments by reducing country's investments directly and complementary expenditure indirectly. The uncertainty created by debt in the shape of possibilities of default, adversely affect investor sentiments and thereby future inflows and additional lending. The third stand of the impact of public debt suggests a nonlinear trend among public debt and economic growth (eg., Saira 2016; Kobayashi 2015; Weerasinghe 2010). Under the nonlinear relationship, public debt positively affects economic growth up to a certain point, referred to as the "threshold level" and thereafter it inverts into a negative impact (Mencinger 2014).

A number of studies have been carried out to examine the effect of public debt on economic growth and they provide inconsistent and mixed results. Most studies generally focus on public external debt, while others have analysed both external and domestic debt. Various methods including Ordinary Least Square (OLS), Engle-Granger Cointegration test, Johanson Maximum Likelihood Cointegration test with Vector Auto Correction Model (VECM), Autoregressive Distributed Lag (ARDL) model, Standard Panel data model and Generalised Method of Moment (GMM) have been used to estimate the regressions. In the context of Sri Lanka, there are limited studies: e.g., Fonseka and Ranasinghe (2008), Kumara and Cooray (2013), Akram (2013), which have addressed the issue of increasing public debt and its impact on the country's economic growth. Thus, the author aims to fill this gap in the literature by carrying out a comprehensive analysis extending the data set for the last 41 years. Further, the

\footnotetext{
${ }^{2}$ In this study, Central Government Debt of Sri Lanka, which comprises both domestic and foreign debt, is considered as the public debt.
} 
study hopes to investigate both long run and short run impacts of increasing public debt on economic growth and investment in Sri Lanka.

The rest of the paper is divided into five sections: section two provides an overview on the nexus of public debt and economic growth in Sri Lanka; section three describes the empirical evidences covering the theoretical background. The research methodology applied to estimate the models is described in section four, while the interpretation of the results is reported in section five. Finally, section six provides the conclusion and recommendations of the study.

\section{Nexus between public debt and economic growth in Sri Lanka: an overview}

Sri Lanka's outstanding government debt has gradually mounted to a staggering level over the past few decades and in some periods, it has been recorded to be above GDP. The central government debt in Sri Lanka, which reported 17 as a percentage of GDP 3 in 1950 increased to 34 per cent, 64 per cent, 77 per cent, 97 per cent and 97 per cent, respectively in the 1960s, 1970s, 1980s, 1990s and 2000s. The debt to GDP ratio peaked at 109 per cent in 1989, and was above 100 per cent during the periods of 1988-1989 and 2001-2004 before stagnating around 78 per cent during 2005-2017 (Figure 1).

In terms of the composition of total debt, Sri Lanka tended to highly depend on foreign debt with the liberalization of the economy in 1977. As a result, the share of foreign debt in the total debt portfolio gradually increased to 62 per cent in 1989 from 28 per cent in 1976. The share of foreign debt stood at 36 per cent in 2017 (Figure 1).

Figure 1: Outstanding government debt as a percentage of GDP

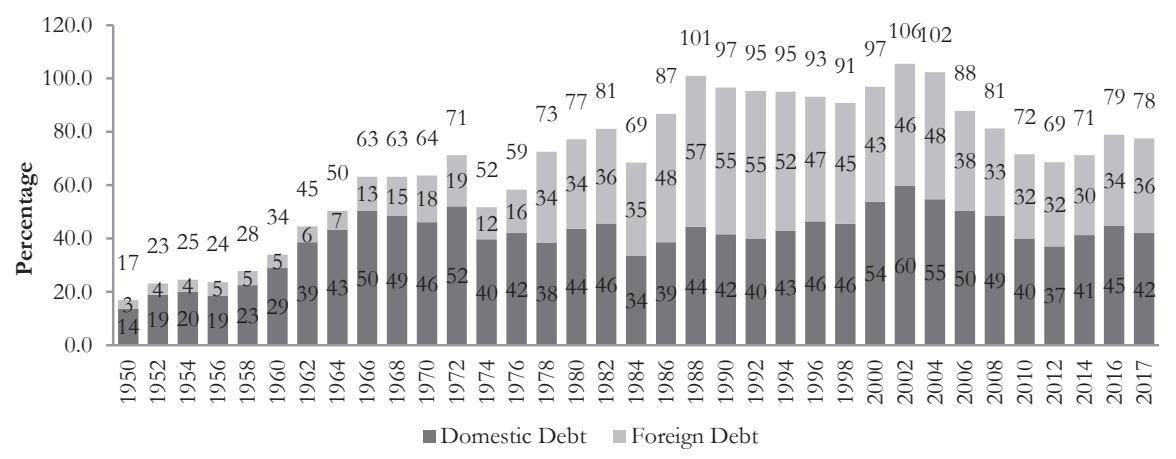

Sources: Central Bank of Sri Lanka and Ministry of Finance

3 The debt-to-GDP ratio, which is calculated by using total nominal debt outstanding at the numerator and the size of nominal GDP at the denominator and expressed as a percentage, is a widely used measure for this purpose (Siddiqui 2001). 
The foreign debt stock of Sri Lanka consists of both loans obtained with concessional terms as well as with non-concessional or commercial terms. As a percentage of total foreign debt, the concessional financing stood at 97 per cent and 99 per cent in 1995 and 2000, respectively. However, the availability of concessional financing for Sri Lanka turned to a decline rapidly following Sri Lanka's elevation to a lower middle income status in 2010 (International Monetary Fund (IMF) 2011; CBSL Annual Report 2010). Accordingly, the ratio of concessional financing gradually declined to 45 per cent in 2017 from over 90 per cent, which was the case prior to 2007 (Figure 2). This paradigm shift has resulted to increase the interest payments causing high deficits, and consequently further accumulating the debt stock in Sri Lanka.

Figure 2: Per capita GDP vs foreign debt concessionality

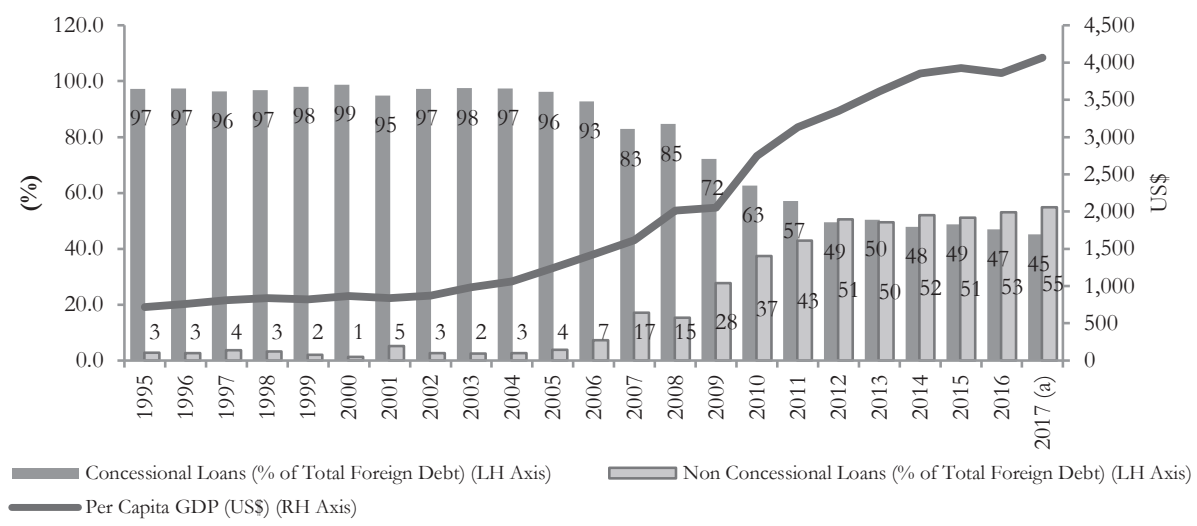

Sources: Central Bank of Sri Lanka and Ministry of Finance

Although Sri Lanka's debt-to-GDP ratio has declined to some extent over the last decade, it still remains relatively high when compared to other frontier markets/rating peers in the region (IMF 2018) (Table 1).

Table 1: Government debt to GDP ratio in selected Asian countries

\begin{tabular}{lcccc}
\hline \hline Country & $\mathbf{1 9 9 0}$ & $\mathbf{2 0 0 0}$ & $\mathbf{2 0 1 0}$ & $\mathbf{2 0 1 7}$ \\
\hline Bangladesh & 51.1 & 31.5 & 36.6 & 33.8 \\
India & 51.5 & 55.8 & 52.2 & 50.3 \\
Maldives & 30.8 & 40.9 & 54.9 & 69.5 \\
Nepal & 52.6 & 57.9 & 34.0 & 26.8 \\
Pakistan & 78.8 & 74.0 & 66.0 & 67.7 \\
Sri Lanka & $\mathbf{9 6 . 6}$ & $\mathbf{9 6 . 9}$ & $\mathbf{7 1 . 6}$ & $\mathbf{7 7 . 6}$ \\
Vietnam & NA & 31.4 & 48.1 & 61.5 \\
\hline
\end{tabular}

Sources: World Development Indicators, World Bank, World Economic Outlook Database, Reserve Bank of India and State Bank of Pakistan 
Various factors have contributed to the debt accumulation in Sri Lanka. Persistently generated low government's tax revenue has adversely contributed towards continuous budget deficits in the country over the past few decades (CBSL Annual Report 2015). The relatively high government expenditure, mainly driven from recurrent expenses have also contributed to increase the budget deficit in the country. Consequently, the high level of government debt of Sri Lanka emanating from continuous high budget deficits have prevailed for several decades, particularly after 1977 (Deyshappriya 2012) (Figure 3). The budget deficit, which was around 5 per cent of GDP on average, during the period 1950-1977 increased to 11 per cent during the period 1978 to 1990, mainly due to the large infrastructure development projects such as Accelerated Mahaweli Development Programme, that were implemented since 1977 (Sanderane 2011). In addition, Sri Lanka's post-civil war mega reconstruction projects, particularly implemented in the affected areas largely utilised the government expenditure contributing to high budget deficits and debt accumulation (Naranpanawa 2017). Further, the inflated government sector as reflected by increasing employees, government institutions and ministries together with various subsidy programmes has also contributed to a large fiscal deficit and thereby higher debt accumulation environment in the country (Sanderathne 2011; Fonseka 2008).

Figure 3: Government revenue, expenditure, budget deficit \& debt to GDP

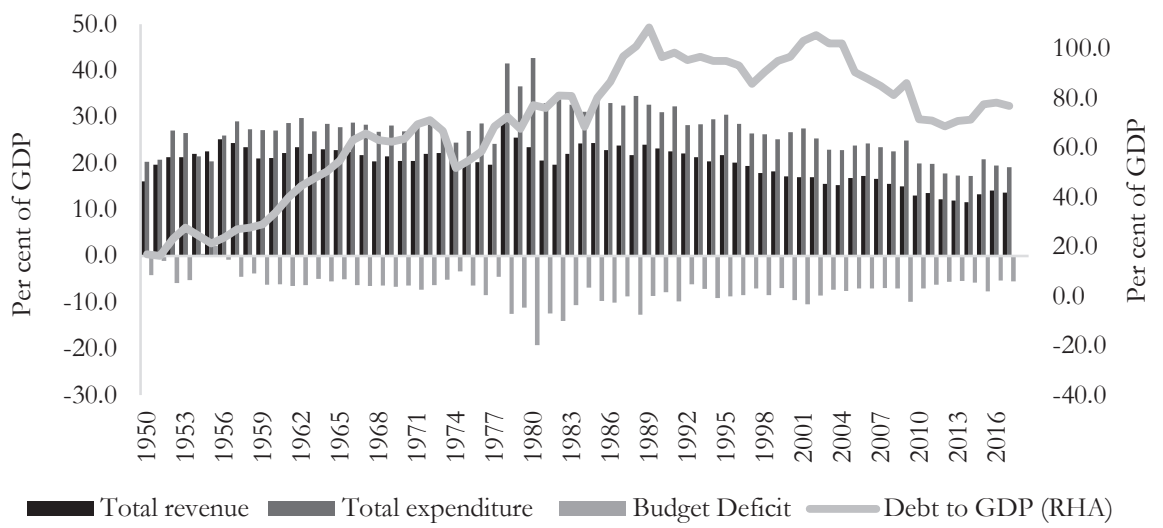

Sources: Central Bank of Sri Lanka and Ministry of Finance

Increasing public debt is believed to have some adverse effects on economic growth in the country causing detrimental impacts on maintaining macroeconomic fundamentals. Accordingly, the sharp increase in cumulative debt stock has resulted in an increase of the debt service payments in the country, largely consuming government's revenue in every year (Table 2). This 
would create an upward pressure on the market interest rates occurring the crowding out of private investments (CBSL Annual Report 2017; Deshappriya 2012). The large budget deficits resulted by higher debt service expenditure induce the government to borrow more and more (Deyshappriya 2012), thus creating conditions to expose it towards a 'debt trap' or the 'vicious cycle of debt'. Meanwhile, high debt service payments have exerted some pressure on Balance of Payment (BOP) problems and financial stability through their impact on interest rates, currency over-valuation, and availability of credit and erosion of country's creditworthiness. In addition, high budget deficit and resulted debt levels can make spillover effects to other sectors of the economy, adversely impacting the macroeconomic stability in the country (CBSL Annual Report 2017).

Table 2: Government debt service payments

\begin{tabular}{lcccccc}
\hline \hline \multicolumn{1}{c}{ Item } & $\mathbf{1 9 9 0}$ & $\mathbf{1 9 9 7}$ & $\mathbf{2 0 0 2}$ & $\mathbf{2 0 0 7}$ & $\mathbf{2 0 1 2}$ & 2017(a) \\
\hline Debt Service Payments (Rs.bn) & 33 & 93 & 284 & 501 & 1,017 & 1,603 \\
Amortisation Payment (Rs.bn) & 12 & 37 & 168 & 318 & 609 & 867 \\
$\quad$ Interest Payments (Rs.bn) & 21 & 55 & 117 & 183 & 408 & 736 \\
Debt Service Payments as \% of GDP & 10.2 & 10.4 & 18.0 & 14.0 & 13.4 & 12.1 \\
$\begin{array}{l}\text { Debt Service Payments as \% of Total } \\
\text { Revenue }\end{array}$ & 48.4 & 56.1 & 108.6 & 88.6 & 96.8 & 87.5 \\
\hline Source: CBSL Annual Reports & & & & & & \\
$\quad$ (a) Provisional & & & & &
\end{tabular}

Although higher accumulation of public debt has some adverse effects on the economy, in many cases, government financing has been playing a major role in the process of economic development in Sri Lanka as indicated by the improved socio economic and human development indicators (Table 3). With the liberalisation of the economy in 1977, the government borrowings increased significantly, while on the other hand, the investment ratio gradually exceeded 20 per cent of GDP. Consequently, Sri Lanka was able to achieve more than 5 per cent average growth of GDP over the period of 1978-2017. It is also observed that most of the infrastructure needs such as education, health and social welfare have been upgraded through external borrowings as indicated by improved human development indicators. Other macroeconomic indicators such as per capita GDP and domestic savings also show progress in line with the various infrastructure development projects implemented in the country. 
Table 3: Selected socio-economic indicators for the period 1990-2017

\begin{tabular}{lcccccc}
\hline \hline Item & $\mathbf{1 9 9 0}$ & $\mathbf{1 9 9 7}$ & $\mathbf{2 0 0 2}$ & $\mathbf{2 0 0 7}$ & $\mathbf{2 0 1 2}$ & $\mathbf{2 0 1 7}$ (a) \\
\hline GDP Growth (\%) & 6.4 & 6.3 & 4.0 & 6.8 & 9.1 & 3.1 \\
Per Capita GDP at Market Price (US\$) & 473 & 814 & 870 & 1,634 & 2,922 & 4,065 \\
Unemployment Rate (\%) (b) & 15.9 & 10.5 & 8.8 & 6.0 & 4.0 & 4.2 \\
Investment as a \% of GDP & 22.2 & 24.4 & 21.2 & 28.0 & 39.1 & 36.5 \\
Domestic Savings as a \% of GDP & 14.3 & 17.3 & 14.4 & 17.6 & 27.3 & 29.3 \\
Term of Trade (\% change) & -12.5 & 6.8 & 4.6 & -1.0 & 1.5 & 1.2 \\
Human Development Index & 0.626 & 0.662 & 0.697 & 0.731 & 0.757 & 0.766 \\
\hline \hline
\end{tabular}

Sources: CBSL Annual Reports and World Development Indicators

(a) Provisional

(b) Percentage of labour force

\section{Literature survey}

\subsection{Empirical evidence}

Egbetunde (2012) points out that public debt would have had a clear positive impact on economic growth in Nigeria if the government had utilised such borrowings for productive investment purposes rather than personal benefit schemes. Time series data over the period 1970-2010 and a standard VAR model has been used to estimate the results. Similar results are observed by Victor and Christoper (2016), examining the causal relationship between public debt and economic growth in Ghana covering the period from 1970 to 2012. Johanson Cointegration with VECM technique were employed to estimate the relevant regressions. Using a Two Stage Least Square (TSLS) regression technique, Saifuddin (2016) comes to the same conclusion in the context of Bangladesh during 1974-2014. Another positive and significant relationship between public debt and economic growth is suggested by Mohanty and Mishra (2016) for 14 major States in India using a cointegration in panel data. This study also found bidirectional causality among public debt and economic growth over the period 1980-2013. Employing an OLS method and time series data for the period 1988 to 2013, Ntshakala (2014) suggests similar positive results for Swaziland. Wibowo (2017) evaluates the correlation between public debt and economic growth in Southeast countries using annual data from 2006 to 2015 and VAR approach. It is concluded that public debt has a significant positive influence on economic growth in these countries. In contrast, Mhlaba and Phiri (2017) find that public debt negatively affects on economic growth in the long run in South African countries. However, in the short run, it is revealed that public debt positively influences economic growth in these countries. They estimate the outcomes using a ARDL model including cointegration and VECM techniques with a sub-samples dataset covering the period from 2002:q2 to 2016:q4. Employing OLS approach to cointegration technique, Atique and Malik (2012) conclude a study suggesting that both domestic and external debt negatively 
effect on the economic growth in Pakistan for the period 1980-2019. In this case, the negative impact of external debt is much stronger than the domestic impact. Akram (2011) also comes to the same conclusion about Pakistan reporting that both foreign and domestic public debt have a significant and negative impact on economic growth and investment. The respective results were estimated applying an ARDL model and using time series data for the period of 1972-2009. Akram (2016) adds another study to the literature investigating the consequences of public debt on economic growth and poverty in South Asian countries for the period 1975 to 2010. In this case, he finds mixed results with regard to the effect of foreign and domestic debt on economic growth and poverty. Pegkas (2018), focusing annual data over the period 1970 -2016 and using ARDL and VECM techniques reveals a significant and long run negative association between public debt and economic growth in Greece, particularly after the year 2000. Munir (2015) investigates a nonlinear relationship between public debt and economic growth for South Asian countries during 1992-2013. He applies a panel fixed effects estimation procedure to approximate the outcomes and finds that public debt positively affects economic growth up to a certain level and thereafter it negatively affects economic growth. It also reveals the basic channels through which public debt affect economic growth, including private investment, public investment and factor of productivity. Similarly, Saeed and Islam (2016) explore a significant and positive nonlinear association between public debt and economic growth in selected Asian countries including Sri Lanka. This has been conducted under the endogeneity and non-linearity covering the period from 1980 to 2014. Using the data for three Asian countries during 1975 -1998, Siddiqui and Malik (2001) estimate a growth model to find the relationship among foreign debt and economic growth with its nonlinearities. In contrast to their expected results, the study suggests a positive and significant impact of foreign debt on economic growth among these countries. Highlighting a nonlinear association, Elements et. al, (2003) point out that higher external debt beyond 50 per cent of GDP causes to reduce the economic growth in low income countries during 1970-1999. They also suggest that economic growth affects public debt indirectly thorough a channel of public investment using fixed effects and GMM techniques. Similarly, Mencingen, Aristovnik and Verbic (2014) also propose a nonlinear relationship for 25 European Union (EU) countries over the period of 1980-2010. The study reveals that the critical threshold level is in the range of 80-90 per cent for old member countries, while it is 53-54 per cent for new member countries. Differently, Panizza et, al, (2012) suggest that there is no causal link between public debt and economic growth in a sample of 17 OECD countries by using an instrumental variable approach.

With regard to the Sri Lankan context, Kumara and Cooray (2013) assess the relationship between public debt and economic growth, while examining the optimal threshold rate of debt sustainable for Sri Lanka covering the period of 1960-2010. The study reveals that there is a nonlinear relationship between the public debt and GDP per capita growth in Sri Lanka and the optimal threshold level for public debt is 59.42 per cent of GDP. Using two step model 
specifications, Akram (2017) explores a direct positive relationship between the public debt and economic growth in Sri Lanka, while observing a significant positive causality between public debt and investment. For the study, time series data for the period of 1975-2014 and ARDL model including VECM techniques were employed. In contrast, he finds a negative relationship between debt service payments and economic growth, reflecting a crowd out investment in the economy. Reaching a similar conclusion, Aslam (2016) finds a significant long run positive relationship between budget deficit and economic growth in Sri Lanka for the period of 1959-2013. The respective outcomes are estimated using a Johanson Cointegration maximum likelihood technique with VECM model. Another Sri Lankan university study has been conducted by Silva and Perera (2015), indicating a positive association between public debt and gross domestic product in Sri Lanka during 2000-2014. In contrast, Fernando et. al, (2017) conducted a comprehensive analysis and found that the low quality of borrowings from commercial sources is a key factor in determining the impact of debt on economic growth and it showed a negative effect on economic growth in Sri Lanka. This is revealed using an ARDL model and annual data from 1960 to 2015. Meanwhile, using a Johansen cointegration approach followed by VECM, Attapattu and Padmasiri (2018) conclude that public debt has a long run negative association with economic growth in Sri Lanka during 1977-2012. Similarly, Ekanayake (2011) concludes that one standard deviation growth shock (positive) will reduce the debt to GDP ratio by 2.4 per cent by 2015 in Sri Lanka.

\subsection{Theoretical models}

Public debt is an accumulated value of borrowings used to finance the government's budget deficit (Wibowo 2017). This implies that public debt plays a major role in fiscal operations, particularly in determining the government's expenditure. The role of public debt in an economy has been discussed in several theoretical models (Akram 2017). However, based on economic effects of budget deficit, these theoretical models can be broadly divided into three schools of thought namely; Neoclassical, Keynesian and Ricardian (Bernheim 1989).

\subsubsection{Neoclassical Growth Model}

According to the neoclassical growth model developed by Solow (1956), economic growth can be achieved by increasing savings and investments. These activities need to be financed through internal sources such as taxes and non tax revenue. However, if the tax and non tax revenue (domestic savings), particularly in developing countries are not sufficient to cover the essential investments that are required for economic development, they have to finance such investments using government borrowings. This implies that the utilisation of such borrowings for productive investments would enhance economic activities, reflecting the direct impact of public debt on economic growth. On the other hand, the decline in domestic savings will lead to an increase of interest rates, resulting in a crowding out private investment in the economy. The theory also argues that higher debt service payments, emanating from 
large foreign debt accumulation would create crowding out government expenditure, indicating the negative correlation between public debt and economic growth.

\subsubsection{Keynesian Growth Model}

According to the Keynesian model as highlighted by Bernheim (1989), increasing government expenditure and expansionary fiscal policies are considered main determinants in the process of economic growth. This indicates that increasing government expenditure and decreasing taxes will enhance the aggregate demand, and thereby the economic growth. For instance, an increase in budget deficit by 1 rupee will expand the output by the inverse of the marginal propensity to save. On the other hand, expansion of the output will raise the money demand, exerting upward pressure on the market interest rates and thereby creating crowding out private investments in the economy. In contrast, Keynesian theory also emphasises the importance of a surplus budget as it is supportive to decrease the government borrowings. Therefore, the Keynesian paradigm focuses on flexible views concerning the short run effect.

\subsubsection{Classical Growth Model}

According to the Ricardian theory, governments finance their expenditure using either tax income or borrowings from external and internal sources. If governments use borrowings to finance their expenditure, they will have to repay the amortisation and interest payments on borrowed funds by increasing future taxes on the public. This implies that the net impact of borrowings is almost similar to financing the government expenditure through taxes, suggesting that there is no impact on the aggregate demand. Empirical evidence has also argued that investors are expecting an increase tax rates in the future with the higher debt accumulation. This investor expectation leads to slow down further investments in the economy, reflecting its negative impact on economic growth (Munir 2015).

\subsection{Theories of Debt and Growth}

In the literature, three important theories discuss about the impact of public debt on economic growth (Ngugi 2016).

\subsubsection{Crowding in Effect}

Theoretical arguments suggest that if a government utilises its borrowed funds in productive investment purposes effectively and in an efficient manner, that will lead to enhance a country's economic growth (Mhlaba 2017). However, if a country heavily relies on government borrowings, that will result to increase the debt accumulation stock, creating various fiscal risks. 


\subsubsection{Crowding out Effect}

It is argued that if a government utilises its borrowings largely for unproductive purposes that will prevent the sufficient investments in the country, it would lead to a slowdown in the economic growth. In such a situation, increasing public debt is known as a barometer of loose fiscal policy (Kobayashi 2015). The theory also argues that the crowding out investment occurs mainly due to a rise in market real interest rates. Further, the literature discusses this theory as borrowings increase the current consumption shifting the tax burden for the future generations (Ngugi 2016). Higher current consumption, on the other hand, reduces the domestic savings, exerting upward pressure on the market interest rates. This in turn causes to reduce the private investments, reflecting the crowding out impact in the economy.

\subsubsection{Debt Overhang Theory}

According to the debt overhang theory developed by Krugman (1988), foreign debt has a positive impact on economic growth until a certain level, and beyond that level, the marginal impact of an additional debt on economic growth will reduce. This is because continuous increase in debt stock could be larger than the country's repayment ability in the future. This is likely to increase the expected debt service costs discouraging further investments and adversely affecting the economic growth (Mhlaba 2017). On the other hand, higher interest payments on foreign debt will increase the budget deficit creating a lower national savings environment in the country. Consequently, high interest rates can drive up crowding out the resources available for private investments, particularly in the areas of infrastructure development, education, health and other social activities. Moreover, the possibility of default of the debt servicing will also create uncertainty among the investors, adversely affecting the stability of the future inflows (Akram 2017). This will reduce the productivity of capital and thereby economic growth.

\subsection{Theoretical Framework}

In this section, a simple model is developed to show the macroeconomic relationship between economic growth and public debt following the neoclassical growth model and the previous research studies (eg., Nantwi 2016; Erickson 2016). The neoclassical growth model (Solow) argues that the increasing government expenditure is believed to be an important investment in human capital such as education, health and infrastructure. Considering the fact that, if the government debt is raised for financing such productive investments, it is argued that the government's borrowings will increase the output mainly through enhanced capital (K), labour $(\mathrm{L})$, technology (A) and other factors $(\mathrm{N})$. This relationship can be shown by an aggregate production function as follows;

$$
Y_{t}=A f\left(K_{t}, L_{t}, N_{t}\right)
$$


where, $\mathrm{Y}_{\mathrm{t}}$ is growth of aggregate output (GDP) at time $t, A$ is level of technology, $\mathrm{K}_{\mathrm{t}}$ is stock of capital at time $t, \mathrm{~L}_{\mathrm{t}}$ is labour force at time $t$ and $\mathrm{N}_{\mathrm{t}}$ is the vector of other factors including public debt, that affected on economic growth at time $t$.

In order to express the equation (1) in a growth terms, total derivatives are taken and the respective equation is given by the following form.

$$
\frac{\partial Y_{t}}{Y_{t}}=\frac{\partial A_{t}}{A_{t}}+A \cdot \frac{\partial Y_{t}}{\partial K_{t}} \cdot \frac{\partial K_{t}}{Y_{t}}+A \cdot \frac{\partial Y_{t}}{\partial L_{t}} \cdot \frac{\partial L_{t}}{Y_{t}}+A \cdot \frac{\partial Y_{t}}{\partial N_{t}} \cdot \frac{\partial N_{t}}{Y_{t}}
$$

or

$$
\frac{\partial Y_{t}}{Y_{t}}=\frac{\partial A_{t}}{A_{t}}+A \cdot \frac{\partial Y_{t}}{I_{t}} \cdot \frac{I_{t}}{Y_{t}}+A \cdot \frac{\partial Y_{t}}{\partial L_{t}} \cdot \frac{\partial L_{t}}{Y_{t}}+A \cdot \frac{\partial Y_{t}}{\partial N_{t}} \cdot \frac{f X_{i t}}{Y_{t}}
$$

where, $\partial K_{t}=I_{t}$ (Changes in capital stock is equivalent to the change in gross domestic capital formation, $I$, in each year).

$\partial N_{t}=f X_{i t}$ (Change in other independent variables including debt variables (vector), which is assumed to be equivalent to the value of each variable, $i$ ).

Incorporating above arguments, a new equation can be obtained as follows;

$$
\frac{\partial Y_{t}}{Y_{t}}=\frac{\partial A}{A}+\left\{A \cdot \frac{\partial Y_{t}}{\partial I_{t}} \cdot \frac{I_{t}}{Y_{t}}\right\} \cdot \frac{\partial I_{t}}{I_{t}}+\left\{A \cdot \frac{\partial Y_{t}}{\partial L_{t}} \cdot \frac{L_{t}}{Y_{t}}\right\} \cdot \frac{\partial L_{t}}{L_{t}}+\left\{A \cdot \frac{\partial Y_{t}}{\partial N i_{t}}\right\} \cdot \frac{\partial f X_{i t}}{Y_{t}}
$$

We can express the equation (3) in a simple way as follows;

$$
\frac{\Delta Y_{t}}{Y_{t}}=\alpha_{0}+\alpha_{1} \frac{\Delta I_{t}}{I_{t}}+\alpha_{2} \frac{\Delta L_{t}}{L_{t}}+\alpha_{3 i} \cdot \frac{f X_{i t}}{Y_{t}}
$$

Where;

$$
\alpha_{0}=\frac{\partial A}{A}, \quad \alpha_{1}=A \cdot \frac{\partial Y_{t}}{\partial I_{t}} \cdot \frac{I_{t}}{Y_{t}}, \quad \alpha_{2}=A \cdot \frac{\partial Y_{t}}{\partial L_{t}} \cdot \frac{L_{t}}{Y_{t}}, \alpha_{3 i}=A \cdot \frac{\partial Y_{t}}{\partial N i_{t}}
$$

For the estimation purposes, the growth equation (4) can be expressed in the reduced vector form (Clements (2003)] as; 


$$
G_{t}=\alpha_{0}+\alpha_{1} I_{t}+\alpha_{2} L_{t}+\sum_{i=1}^{n} \alpha_{3 i} f X_{i t}+\mu_{t}
$$

where, $G_{t}$ is GDP growth rate at time $t, I_{t}$ is growth of investment to GDP ratio at time $t, L_{t}$ is growth of labour force, $f X_{i t}$ is a vector of other independent variables including public debt ratios, which measured as a percentage of GDP, $n$ represents the number of variables, $\alpha_{1}$ is elasticity of GDP growth with respect to the change in investment, $\alpha_{2}$ is elasticity of GDP growth with respect to change in labour force, $\alpha_{3 i}$ is elasticity of GDP growth with respect to change in other independent variables including public debt ratios and $\mu_{t}$ is the error term of the model.

Extending the growth equation (5), we can obtain another reduced vector form (Akram 2011) to capture the effect of public debt on investment, is given by;

$$
I_{t}=\alpha_{0}+\alpha_{1} G_{t}+\alpha_{2} L_{t}+\sum_{i=1}^{n} \alpha_{3 i} f X_{i t}+\mu_{t}
$$

where, $\alpha_{1}$ is elasticity of investment growth with respect to change in GDP, $\alpha_{2}$ is elasticity of investment growth with respect to change in other independent variables including public debt ratios.

\section{Data and methodology}

\subsection{Choice of methodology}

The study aims to analyse both long run and short run impacts of public debt on economic growth. Therefore, it is more appropriate to use a VECM approach specified under the VAR framework with cointegration technique. This procedure determines both long run and short run effects at the same time, detecting cointergrating vectors. In a situation, that series existence cointergration, using OLS may give spurious results. Further, remaining rich literature on the utilisation of this technique also induced the author to use this method.

\subsection{Data description}

The study is carried out using annual time series data for Sri Lanka covering the period from 1977 to 2017. The main data sources are annual reports of the Central Bank of Sri Lanka (CBSL) and the Ministry of Finance (MOF). All variables used in the study are transformed into their natural logs with the view of eliminating serial correlations and multicollinearity issues (Mohanty 2016). More details about the all variables are summarised in Table 4. 
Table 4: Details of variables

\begin{tabular}{lll}
\hline \hline Name of Variable & Definition of Variable & $\begin{array}{l}\text { Data } \\
\text { Source }\end{array}$ \\
\hline Per Capita GDP (PGDP) & $\begin{array}{l}\text { GDP per capita in current market price (Rs.). This is used as a } \\
\text { proxy for GDP growth. } \\
\text { Private gross capital formation as a \% GDP }\end{array}$ & CBSL \\
Private Investment $\left(I N V_{p}\right)$ & CBSL \\
Public Investment $\left(I N V_{g}\right)$ & Public gross capital formation as a \% of GDP & CBSL \\
Public Domestic Debt $(P D D)$ & Government domestic debt as a \% of GDP & \& MOF \\
Public Foreign Debt $(P F D)$ & Government foreign debt as a \% of GDP & CBSL \\
Total Public Debt $(P T D)$ & Total government debt as a \% of GDP & CBSL \\
Debt Service Payments $(D S P)$ & Government debt service payment as a \% of GDP & CBSL \\
Openness $(O P N)$ & (Export + Import)/GDP*100 & CBSL \\
Population Growth $(P O P)$ & $\begin{array}{l}\text { Population growth rate. This is used as a proxy for labour force in } \\
\text { the country. }\end{array}$ & CBSL \\
Domestic Savings $(D S V)$ & Domestic saving as a \% of GDP & CBSL \\
Inflation $(I N F)$ & Annual consumer price index & CBSL \\
Exchange Rate $(E X R)$ & Average annual exchange rate & CBSL \\
\hline
\end{tabular}

\subsection{Model specification}

In terms of the model specification, the study specifies two models: growth model and investment model following related literature (eg., Element 2003; Chongo 2013; Nisma 2015; Akram 2016). The growth model is used to assess the direct impact of public debt along with other independent variables on economic growth. The investment model is applied to examine the effect of public debt along with other independent variables on investment. This model facilitates the finding of the basic channel through which public debt affects on economic growth. Hence, the investment model explains the indirect relationship between public debt and economic growth.

\subsubsection{Growth model}

Based on the equation (5) described in the section three, the econometric growth model can be specified as;

$$
\begin{aligned}
P G D P_{t}=\alpha_{0} & +\alpha_{1} I N V_{p t}+\alpha_{2} I N V_{g t}+\alpha_{3} P D D_{t}+\alpha_{4} P F D_{t}+\alpha_{5} D S P_{t}+\alpha_{6} O P N_{t} \\
& +\alpha_{7} P O P_{t}+\mu_{1 t}
\end{aligned}
$$


where, $P G D P_{t}$ is the per capita GDP at time $t, I N V_{p t}$ is the private investments at time $t$, $I N V_{g t}$ is the public investments at time $t, P D D_{t}$ is the public domestic debt at time $t, P F D_{t}$ is the public foreign debt at time $t, D S P_{t}$ is debt service payments at time $t, O P N_{t}$ is openness at time $t, P O P_{t}$ is population growth at time $t$ and $\mu_{1 t}$ represents the error term of the growth model. In the model, $P G D P_{t}$ is used as the dependent variable, while all other variables represent the independent variables. In this case, all variables except debt service payments are expected to have a positive correlation with per capita GDP.

Following the Johansen and Juselius (1990/1991), the mathematical growth equation (7) is expressed in its log form and specified in the VAR model for multivariate cointegration test as follows:

$$
\begin{aligned}
\ln P G D P_{t}= & \alpha_{0}+\alpha_{1} \ln I N V_{p t}+\alpha_{2} \ln I N V_{g t}+\alpha_{3} \ln P D D_{t}+\alpha_{4} \ln P F D_{t}+\alpha_{5} \ln D S P_{t}+ \\
& \alpha_{6} \ln O P N_{t}+\alpha_{7} \ln P O P_{t}+\mu_{1 t}
\end{aligned}
$$

The equation (8) is now rewritten in a VECM form as follows;

$$
\begin{aligned}
\Delta \ln P G D P_{t}= & \alpha_{1} \Delta \ln I N V_{p t-1}+\alpha_{2} \Delta \ln I N V_{g t-1}+\alpha_{3} \Delta \ln P D D_{t-1}+\alpha_{4} \Delta \ln P F D_{t-1}+ \\
& \alpha_{5} \Delta \ln D S P_{t-1}+\alpha_{6} \Delta \ln O P N_{t-1}+\alpha_{7} \Delta \ln P O P_{t-1}+\xi_{t-1}+\mu_{1 t}
\end{aligned}
$$

where, $\Delta$ represents the difference operator and $\xi_{t-1}$ represents the lagged value of the Error Correction Term (ECT) derived from long run cointegration vector. This allows to determine the short run dynamics of the growth model.

\subsubsection{Investment model}

Based on the equation (6), the econometric model for investment can be specified in the following form ${ }^{4}$.

$$
\begin{aligned}
I N V_{t}= & \alpha_{0}+\alpha_{1} P G D P_{t}+\alpha_{2} T P D_{t}+\alpha_{3} D S P_{t}+\alpha_{4} D S V_{t}+\alpha_{5} O P N_{t}+\alpha_{6} I N F_{t}+ \\
& \alpha_{7} E X R_{t}+\mu_{2 t}
\end{aligned}
$$

where, $I N V_{t}$ is total investment (private investment + public investment) at time $t, \mathrm{PGDP}_{\mathrm{t}}$ is the per capita GDP at time $t, \mathrm{TPD}_{\mathrm{t}}$ is the total public debt (domestic + foreign) at time $t$, $D S P_{t}$ is debt service payments at time $t, D S V_{t}$ is domestic savings at time $t, O P N_{t}$ is openness

${ }^{4}$ In this case, labour is replaced by domestic savings to make the estimation easier. 
at time $t, I N F_{t}$ is inflation at time $t, E X R_{t}$ is average annual exchange rate at time $t$ and $\mu_{2 t}$ represents the error term of the investment model. In this model, $I N V_{t}$ is the dependent variable, while all other variables including public debt variables are represented by the independent variables. In many cases in related literature, different variables have been used to estimate the investment model compared to the growth model (eg., Saifuddin 2016; Riffat Munir 2015; Chongo 2013; Akram 2010). In this case, PGDP, TPD, DSV, OPN are expected to have positive coefficients, while $D S P, I N F, E X R$ are expected to show negative coefficients.

The mathematical equation (10) can be expressed in its natural log form under the following VAR process:

$$
\begin{aligned}
& \ln I N V_{t}=\alpha_{0}+\alpha_{1} \ln P G D P_{t}+\alpha_{2} \ln T P D_{t}+\alpha_{3} \ln D S P_{t}+\alpha_{4} \ln D S V_{t}+ \\
& \alpha_{5} \ln O P N_{t}+\alpha_{6} \ln I N F_{t}+\alpha_{7} \ln E X R_{t}+\mu_{2 t}
\end{aligned}
$$

The equation (11) is rewritten in a VECM form as follows;

$$
\begin{aligned}
& \Delta \ln I N V_{t}=\alpha_{1} \Delta \ln P G D P_{t-1}+\alpha_{2} \Delta \ln T P D_{t-1}+\alpha_{3} \Delta \ln D S P_{t-1}+\alpha_{4} \Delta \ln D S V_{t-1}+ \\
& \alpha_{5} \Delta \ln O P N_{t-1}+\alpha_{6} \Delta \ln I N F_{t-1}+\alpha_{7} \Delta \ln E X R_{t-1}+\xi_{t-1}+\mu_{2 t}
\end{aligned}
$$

\subsection{Econometric procedures}

Several statistical methods and econometrics tests were carried out to estimate both the long run and short run relationships among the variables of the specified two models.

\subsubsection{Unit Root tests}

In order to test the cointegration among variables, it is required to check the stationarity of each variable as a preliminary step (Edbetunde 2012; Christoper 2016; Aslam 2016). Hence, the stationarity of the time series data was tested using Augmented Dickey-Fuller (1979) and Phillip-Perron (1988) unit root tests. In the literature, these two procedures are well established to determine the characteristics of individual series of the variables.

\subsubsection{Augmented Dickey-Fuller (ADF)}

The ADF test developed by Dickey and Fuller is the most popular technique in the literature for analyzing time series data. The respective regression equation of the ADF unit root is given by the following form. 


$$
\Delta Y_{t}=\beta_{1}+\beta_{2}+\delta Y_{t-1}+\sum \delta_{i} \Delta Y_{t-1}+\mu_{t}
$$

where, $\mathrm{Y}$ represents the relevant variable in the estimation procedure at time $t, \Delta$ is first difference operator, $\mu_{\mathrm{t}}$ is a pure white noise error term with zero value of mean and constant variance. In the equation, it is assumed that the error term $\mu_{t}$ is serially uncorrelated and using the $\mathrm{AR}(\mathrm{P})$ process.

\subsubsection{Phillips - Perron (PP)}

PP unit root testing approach was developed by Phillips and Perron in 1988. In the literature, this approach is also much popular in analyzing the time series data. The following form is used to test the stationarity of the variables (Aslam 2016).

$$
\Delta Y_{t}=\beta^{\prime} D_{t}+\pi Y_{t-1}+u_{t}
$$

where, $\mathrm{u}_{\mathrm{t}}$ is $\mathrm{I}(0)$ and may be heteroskedasticity.

The hypothesis for the ADF and PP are $H_{0}=$ The Null hypothesis has unit roots and $H_{1}=$ The Alternative hypothesis has no unit roots (stationary).

\subsubsection{Johansen and Juselius Cointegration test:}

After determining the stationarity of each variable, the Johansen test of multivariate cointegration method, which was developed by Johansen (1991) and Juselius (1990) was applied to test the possibility of having cointegration among 1(I) variables. By testing the cointegration, one can ascertain a stable long run association between the variables (Mohanty 2016; Wibowo 2017; Atapattu 2018). The Johansen cointegration tests are likelihood ratio tests and there are two different test statistics to determine the number of cointegration vectors, including the Trace test and Maximum Eigenvalue test. The trace test and Maximum Eigenvalue test statistics are computed using the following equations (15) and (16), respectively.

$$
\begin{aligned}
& J_{\text {trace }}=-T \sum_{i=r+1}^{n} \ln \left(1-\hat{\lambda}_{i}\right) \\
& J_{\text {max }}=-T \ln \left(1-\hat{\lambda}_{r+1}\right)
\end{aligned}
$$

where, $T$ is the sample size and $\lambda$ is the Maximum Eigenvalue. The Trace statistics examine the null hypothesis of $r$ cointegrating relations opposed to alternative hypothesis of $n$ 
cointegrating vectors. In this case, $n$ is the number of variables in the system for $r=$ $0,1,2 \ldots n-1$. The Maximum Eigenvalue statistics investigate the null hypothesis of $r$ cointegrating vectors against a specific alternative hypothesis of $(r+1)$ cointegrating vectors for $r=0,1,2 \ldots n-1$.

\subsubsection{Vector Error Correction Model (VECM)}

Once examined the cointegrating relationship between series, which implies that there exists a long run equilibrium relationship between the variables, the short run causal relationship of the cointegrated series is determined by estimating a VECM. The variables in VECM are expressed in the first difference. Accordingly, the general regression equation of VECM takes the following form.

$\Delta Y_{t}=\alpha_{1}+P_{1} e_{1}+\sum_{i=0}^{n} \beta_{i} \Delta Y_{t-i}+\sum_{i=0}^{n} \delta_{i} \Delta X_{t-i}+\sum_{i=0}^{n} \gamma_{i} Z_{t-i}$

$\Delta X_{t}=\alpha_{2}+P_{2} e_{i-1}+\sum_{i=0}^{n} \beta_{i} \Delta Y_{t-i}+\sum_{i=0}^{n} \delta_{i} \Delta X_{t-i}+\sum_{i=0}^{n} \gamma_{i} Z_{t-i}$

where, $\alpha_{1}$ and $\alpha_{2}$ are constant. The cointegration rank in VECM determines the number of distinct cointegrating vectors. The Error Correction Term (ECT) shows the speed of adjustment of the state of the equilibrium and it is expected to be negative and significant. A negative and significant coefficient of the ECT indicates that there exists a stable long run relationship between series caused by any short run fluctuations among the variables.

\section{Empirical results}

\subsection{Descriptive analysis of statistics}

Analysing the descriptive statistics of each variable is useful to understand the nature of the distribution of such variables. According to the descriptive statistics (Table A1), low standard deviations (SDs) of all variables indicate the favorable dispersion of the distributions. Relatively low coefficients of skewness and kurtosis show the approximate normality distribution of each variable. Further, the variation between maximum and minimum of each variable is quite favorable, while the ratio of mean to median is closer to 1 . All these indicate that data can be used effectively to continue the estimations. 


\subsection{Results of Unit Root tests}

It is necessary to test the unit roots of each variable prior to determining the cointegrations among such variables as most of time series data are non-stationary. Non-stationary variables may tend to provide spurious regression results without any economic meaning (Attapattu 2018). Hence, the verification of the stationarity of each variable relating to both models was tested by using unit root tests as described in section four. The results of unit roots of all variables are summarised in Table 5 .

The results clearly indicate that all variables are stationary at first differences. However, population growth and exchange rate are stationary at both levels and first difference. Although population growth and exchange rate, which belong to two different models are stationary at both levels and first differences, the study can apply cointegration and VECM techniques to estimate the specified two models as most of the series are integrated of order one I (1) (Nantwi 2017; Akram 2017; Pegkas 2018). In addition to these standard unit root tests, a "Breakpoint Unit Root Test" was also carried out to verify the stationarity of each variable and showed similar results (Table A2). The results of the above unit root tests imply that there is a long run equilibrium relationship among the series without any possibility of having spurious regressions.

Table 5: Unit root analysis for all log variables

\begin{tabular}{lccccc}
\hline \hline & \multicolumn{2}{c}{ Augmented Dickey Fuller (ADF) } & & \multicolumn{2}{c}{ Phillip -Perron (PP) } \\
\cline { 2 - 3 } \cline { 5 - 6 } & Level & First difference & & Level & First difference \\
\hline $\ln P G D P$ & -1.678588 & $11.78755^{*}$ & & -1.432146 & $-5.141078^{*}$ \\
$\ln I N V$ & -0.510917 & $-6.843721^{*}$ & & -3.530147 & $-8.331957^{*}$ \\
$\ln I N V_{g}$ & -2.202477 & $-4.021255^{*}$ & & -1.784306 & $-8.262733^{*}$ \\
$\ln I N V_{p}$ & 0.194805 & $-6.306224^{*}$ & & -2.114215 & $-9.768286^{*}$ \\
$\ln P D D$ & -2.107494 & $-6.318956^{*}$ & & -2.139102 & $-6.319355^{*}$ \\
$\ln P F D$ & -1.695165 & $-7.255984^{*}$ & & -1.828098 & $-7.136285^{*}$ \\
$\ln T P D$ & -2.267403 & $-7.021403^{*}$ & & -2.022429 & $-7.004712^{*}$ \\
$\ln D S P$ & -2.129477 & $-10.05310^{*}$ & & -2.458160 & $-10.25443^{*}$ \\
$\operatorname{lnOPN}$ & -1.944482 & $-9.022518^{*}$ & & -2.310843 & $-9.200885^{*}$ \\
$\ln D S V$ & -1.446786 & $-7.210028^{*}$ & & -1.407411 & $-7.340134^{*}$ \\
$\ln P O P$ & $-7.005876^{*}$ & $-14.28309^{*}$ & & $-6.965996^{*}$ & $-32.02282^{*}$ \\
$\ln I N F$ & -1.839019 & $-7.922255^{*}$ & & -2.887262 & $-7.422694^{*}$ \\
$\ln E C R$ & $-3.505032^{*}$ & $-13.13939^{*}$ & $-3.701159^{*}$ & $-11.42282^{*}$ \\
\hline
\end{tabular}




\begin{tabular}{llcll}
\hline \multicolumn{5}{c}{ Critical Values } \\
\hline $1 \%$ Critical Value & -3.605593 & -3.615588 & -3.605593 & -3.610453 \\
$5 \%$ Critical Value & -2.936942 & -2.941145 & -2.936942 & -2.938987 \\
$10 \%$ Critical Value & -2.606857 & -2.609066 & -2.606857 & -2.607932 \\
\hline
\end{tabular}

$*$ indicates significance at $1 \%, 5 \%$ and $10 \%$.

\subsection{Selection of optimal lag length:}

The optimal lag length used to estimate the specified models is 2 . This was selected using the Akaike Information Criterion (AIC), Final Predictor Error (FPE) and Sequential Modified LR tests. This selection is also consistent with the arguments made by Pesaran et al. (2001) and Akram (2016). They suggest that maximum lag length 2 is more appropriate for the studies that have been conducted using annual data with short data observations. In this study, annual data and only 41 observations with seven parameters for each model are used.

\subsection{Results of cointegration tests, long run and short run equilibrium relationship of the growth model}

\subsubsection{Cointegration results:}

Assuming a linear deterministic trend, the long run effect of public debt on economic growth was tested using a cointegration procedure as discussed in the Section four. The results of the cointegration rank tests; Trace statistics and Maximum Eigen Value statistics, respectively suggest that there exist four and three long run cointegration equilibrium relationship at 5 per cent significant level (Tables 6 and 7). This implies that the hypothesis of no cointegration among variables in the growth model is rejected, indicating a stable long run relationship between economic growth and public debt along with other independent variables.

Table 6: Johansen cointegration rank test results (trace)

\begin{tabular}{|c|c|c|c|c|}
\hline $\begin{array}{c}\text { Cointegration Relations } \\
\text { Null Hypothesis }\end{array}$ & Eigen Value & Trace Statistics & $\begin{array}{c}\text { Critical Value at } \\
5 \% \text { level }\end{array}$ & Probability Value** \\
\hline None * & 0.903294 & 265.9264 & 159.5297 & 0.0000 \\
\hline At most $1 *$ & 0.781470 & 174.8195 & 125.6154 & 0.0000 \\
\hline At most $2^{*}$ & 0.658888 & 115.5070 & 95.75366 & 0.0011 \\
\hline At most $3^{*}$ & 0.545693 & 73.56079 & 69.81889 & 0.0244 \\
\hline At most 4 & 0.320277 & 42.79052 & 47.85613 & 0.1377 \\
\hline At most 5 & 0.312478 & 27.73382 & 29.79707 & 0.0849 \\
\hline At most 6 & 0.198913 & 13.12203 & 15.49471 & 0.1104 \\
\hline At most $7^{*}$ & 0.108345 & 4.472361 & 3.841466 & 0.0344 \\
\hline
\end{tabular}

\footnotetext{
Trace test indicates 4 cointegrating eqn $(\mathrm{s})$ at the 0.05 level. $*$ denotes rejection of the hypothesis at the 0.005 level.
}

** Mackinnon-Haug-Michelis (1999) p-values. 
Table 7: Johansen cointegration rank test results (maximum eigen value)

\begin{tabular}{ccccc}
\hline \hline $\begin{array}{c}\text { Cointegration Relations } \\
\text { Null Hypothesis }\end{array}$ & Eigen Value & $\begin{array}{c}\text { Max-Eigen } \\
\text { Statistic }\end{array}$ & $\begin{array}{c}\text { Critical Value } \\
\mathbf{5 \% \text { level }}\end{array}$ & $\begin{array}{c}\text { at } \\
\text { Probability } \\
\text { Value** }\end{array}$ \\
None ${ }^{*}$ & 0.903294 & 91.10694 & 52.36261 & 0.0000 \\
At most 1* & 0.781470 & 59.31246 & 46.23142 & 0.0012 \\
At most 2* & 0.658888 & 41.94622 & 40.07757 & 0.0304 \\
At most 3 & 0.545693 & 30.77027 & 33.87687 & 0.1124 \\
At most 4 & 0.320277 & 15.05670 & 27.58434 & 0.7437 \\
At most 5 & 0.312478 & 14.61179 & 21.13162 & 0.3170 \\
At most 6 & 0.198913 & 8.649665 & 14.26460 & 0.3165 \\
At most 7* & 0.108345 & 4.472361 & 3.841466 & 0.0344 \\
\hline
\end{tabular}

Max-eigenvale test indicates 3 cointegrating eqn (s) at the 0.05 level. * denotes rejection of the hypothesis at the 0.005 level. ** Mackinnon-Haug-Michelis (1999) p-values.

\subsubsection{Long Run Relationship}

As indicated by the cointegration results, it was found that there is a stable long run association between economic growth and public debt along with other control variables. The estimated long run model of cointegration and corresponding long run coefficients obtained from the VECM are reported in Table 8.

Table 8: Cointegration coefficients from VECM

\begin{tabular}{|c|c|c|c|}
\hline Regressor & Coefficient & Standard Error & T Ratio \\
\hline $\ln P G D P$ & 1.000000 & & \\
\hline $\ln I N V_{p}$ & 15.95286 & $(3.27731)$ & {$[2.23494] *$} \\
\hline $\operatorname{lnINV_{g}}$ & 13.00860 & $(5.82057)$ & {$[2.23494] *$} \\
\hline $\ln P D D$ & 29.16112 & $(4.12455)$ & {$[7.07013] *$} \\
\hline $\ln P F D$ & 18.59824 & (2.77315) & {$[6.70654] *$} \\
\hline $\ln D S P$ & -3.390809 & $(2.93169)$ & {$[-1.85661]$ ** } \\
\hline $\operatorname{lnOPN}$ & 2.355765 & $(8.09584)$ & {$[0.29098]$} \\
\hline $\ln P O P$ & -7.954618 & $(2.73388)$ & {$[-2.90964] *$} \\
\hline
\end{tabular}

$*$ and $* *$ indicate significance at $5 \%$ and $10 \%$ levels, respectively.

According to the results, long run normalised cointegrating coefficients of both domestic and foreign public debt are positive and statistically significant at 5 per cent level. This implies that in the long run, both domestic and foreign public debt positively and significantly influence economic growth in Sri Lanka. During the period under consideration, successive 
governments have borrowed funds significantly to finance the large capital expenditure programmes in the country (Weerasinghe 2010). Some of these capital projects include agriculture related infrastructure development projects, establishment of 200 garment factories (1990), Accelerated Mahaveli programe since 1976, irrigation development projects, Norochcholai Coal Power project (2011), Southern Expressway (2011), Medawachiya-Madu railway development project (2013), Magam Ruhunupura port development project (2010), Mattala International Air Port (2013) and various housing projects. Thus, it could be argued that public debt has positively contributed towards economic growth in the country during the period under review.

Moreover, this positive correlation between public debt and economic growth is supported by a majority of Sri Lankan related studies conducted by Akram (2016), Kumara and Cooray (2013), Aslam (2016) and Silva and Perera (2017). On the global front, the literature has found many positive long run results between public debt and economic growth (eg., Victor 2016; Munir 2015; Wibowo 2017; Ntshakala 2014). This positive conclusion is further affirmed by the results estimated from the investment model of this study. That is, public debt positively influences investment and thereby economic growth. In contrast to the above outcome, Attapattu and Padmasiri (2018) and Ekanayake (2011) have proposed a negative association between public debt and economic growth in Sri Lankan.

Debt service payment shows a negative long run impact on economic growth at 10 per cent significant level. It is inferred that this negative association can be occurred due to crowding out investment emanated from high accumulation of foreign and domestic debt. This conclusion is similar to the findings of the study on Sri Lanka conducted by Akram in 2017. However, the overall impact of increasing public debt on economic growth indicates a favorable sign as the negative impact of crowding out investment is outweighed by the positive effect of total public debt on economic growth.

As expected, both public and private investments show a positive and significant long run impact on economic growth, reflecting an increase in production capacity with enhanced capital formation. These findings are also consistent with the theoretical evidence and most empirical evidence. The results of the openness reveal an insignificant positive link to economic growth in the long run. This result is supported by some previous studies (Elements 2003; Zeaud 2014; Akram 2016). In contrast to envisaged outcomes, population growth shows a negative long run impact on economic growth at 5 per cent significant level. This proposition is consistent with various studies (Siddiqui 2001; Zeaud 2014; Riffat 2015; Akram 2017). They argue that the population growth can have both positive and negative impacts on economic growth based on which side of the economy it affects. For instance, higher population in South Asian countries leads to increase poverty, creating more burdens in their economies. Further, higher population growth may hinder economic growth and cause to reduce productivity of these countries. 
As reported in Table 9, the significant ECT further confirms above discussed long run cointegration relationships among variables. The ECT, which measures the speed of adjustment of disequilibrium, is significant with negative signs $(-0.08100)$. The coefficient of the ECT also suggests that, the previous year's disequilibrium in per capita GDP adjusts by 8.1 per cent in the current year to long run equilibrium.

\subsubsection{Results of VECM and short run relationship}

The short run dynamic relationships among variables associated with the long run estimates were assessed by applying a VECM. The short run results of the VECM are tabulated in Table 9.

According to the short run results, one period lagged of public domestic debt has a negative correlation to per capita GDP at 5 per cent significant level. This conclusion is consistent with a Sri Lankan study conducted by Akram (2017). Meanwhile, one period lagged private investment and two periods lagged public investment show a statistically significant positive effect on economic growth parallel to the long run impact. This is also consistent with the Keynesian theory and some empirical evidence. However, all other variables observed that there exist insignificant short run effects on economic growth.

Table 9: VECM regression results of the growth model

\begin{tabular}{lcccc}
\hline \hline Dependent Variable: $\operatorname{lnPGDP}$ & & & & \\
& Coefficient & Standard Error & T Ratio & Probability \\
\hline$E C T *$ & -0.08100 & 0.00365 & -2.21733 & 0.0383 \\
$\ln P G D P(-1)$ & -0.33726 & 0.25380 & -1.32887 & 0.1989 \\
$\ln P G D P(-2) *$ & 0.78918 & 0.30364 & 2.59908 & 0.0172 \\
$\ln I N V_{p}(-1) * *$ & 0.16549 & 0.08409 & 1.96808 & 0.0631 \\
$\ln I N V_{p}(-2)$ & 0.03477 & 0.09152 & 0.37991 & 0.7080 \\
$\ln I N V_{g}(-1)$ & 0.10932 & 0.06566 & 1.66482 & 0.1115 \\
$\ln I N V_{g}(-2) * *$ & 0.11044 & 0.05880 & 1.87832 & 0.0750 \\
$\ln P D D(-1) *$ & -0.46127 & 0.20112 & -2.29354 & 0.0328 \\
$\ln P D D(-2)$ & 0.25581 & 0.22354 & 1.14430 & 0.2660 \\
$\ln P F D(-1)$ & 0.04166 & 0.13342 & 0.31223 & 0.7581 \\
$\ln P F D(-2)$ & -0.08142 & 0.11376 & -0.71571 & 0.4824 \\
$\ln D S P(-1)$ & 0.11454 & 0.06661 & 1.71977 & 0.1009 \\
$\ln D S P(-2)$ & 0.06707 & 0.07406 & 0.90567 & 0.3759 \\
$\ln O P N(-1)$ & 0.09816 & 0.15362 & 0.63899 & 0.5301 \\
$\ln O P N(-2)$ & 0.04302 & 0.08754 & 0.49146 & 0.6284 \\
$\ln P O P(-1)$ & 0.04969 & 0.03174 & 1.56532 & 0.1332 \\
$\ln P O P(-2)$ & 0.02146 & 0.02322 & 0.92404 & 0.3665 \\
Constant & 0.06757 & 0.04467 & 1.51286 & 0.1460 \\
R-squared & 0.63646 & Mean dependent var & 0.1353 \\
S.E. of regression & 0.04627 & S.D. dependent var & 0.0564 \\
Sum squared resid & 0.04281 & Akaike info criterion & -3.0034 \\
& & & & \\
\hline
\end{tabular}




\begin{tabular}{lccc}
\hline \hline Log likelihood & 75.0638 & Schwarz criterion & -2.2277 \\
F-statistic & 2.05966 & Hannan-Quinn criter. & -2.7274 \\
Prob(F-statistic)** & 0.06188 & Durbin-Watson stat & 2.0973 \\
\hline
\end{tabular}

Note: ${ }^{*}$ and $* *$ indicate significance at $5 \%$ level and $10 \%$ level, respectively.

Above short run relationships were further confirmed by estimating Wald tests (Table A3). According to the Wald test, public domestic debt and private investment showed a significant causal relationship to the per capita GDP in the short run, while others indicate no significant association to the per capita GDP. The Wald test also reveals a bidirectional causality between per capita GDP and foreign debt in the short run. This implies that when economic activities in the country improve, the government tends to borrow more foreign debt to enhance the ongoing economic process.

\subsection{Results of cointegration tests, long run and short run equilibrium relationship of the investment model}

\subsubsection{Cointegration results}

The results of the Trace statistics and Maximum Eigen Value statistics of the investment model suggest that there exist four significant long run cointegration equilibrium relationships among the variables (Tables 10 and 11). Similar to the growth model, this indicates that the hypothesis of no cointegration is rejected, suggesting a stable long run association between investment and public debt along with other control variables.

Table 10: Johansen cointegration rank test results (trace)

\begin{tabular}{|c|c|c|c|c|}
\hline $\begin{array}{c}\begin{array}{c}\text { Cointegration } \\
\text { Relations }\end{array} \\
\text { Null Hypothesis }\end{array}$ & Eigen Value & Trace Statistics & $\begin{array}{c}\text { Critical Value at } \\
\mathbf{5 \%} \text { level }\end{array}$ & $\begin{array}{c}\text { Probability } \\
\text { Value** }\end{array}$ \\
\hline None* & 0.943981 & 314.6054 & 159.5297 & 0.0000 \\
\hline At most $1^{*}$ & 0.846392 & 205.0868 & 125.6154 & 0.0000 \\
\hline At most $2^{*}$ & 0.741980 & 133.8993 & 95.75366 & 0.0000 \\
\hline At most $3^{*}$ & 0.672621 & 82.41994 & 69.81889 & 0.0035 \\
\hline At most 4 & 0.393962 & 39.98774 & 47.85613 & 0.2230 \\
\hline At most 5 & 0.297767 & 20.95688 & 29.79707 & 0.3603 \\
\hline At most 6 & 0.166715 & 7.524273 & 15.49471 & 0.5176 \\
\hline At most 7 & 0.015507 & 0.593864 & 3.841466 & 0.4409 \\
\hline
\end{tabular}

Trace test indicates 4 cointegrating eqn (s) at the 0.05 level. * denotes rejection of the hypothesis at the 0.005 level.

** Mackinnon-Haug-Michelis (1999) p-values. 
Table 11: Johansen cointegration rank test results (maximum eigen value)

\begin{tabular}{|c|c|c|c|c|}
\hline $\begin{array}{c}\begin{array}{c}\text { Cointegration } \\
\text { Relations }\end{array} \\
\text { Null Hypothesis }\end{array}$ & Eigen Value & $\begin{array}{c}\text { Max-Eigen } \\
\text { Statistic }\end{array}$ & $\begin{array}{c}\text { Critical Value at } \\
5 \% \text { level }\end{array}$ & $\begin{array}{c}\text { Probability } \\
\text { Value** }\end{array}$ \\
\hline None * & 0.943981 & 109.5187 & 52.36261 & 0.0000 \\
\hline At most $1^{*}$ & 0.846392 & 71.18745 & 46.23142 & 0.0000 \\
\hline At most $2^{*}$ & 0.741980 & 51.47936 & 40.07757 & 0.0017 \\
\hline At most $3^{*}$ & 0.672621 & 42.43220 & 33.87687 & 0.0038 \\
\hline At most 4 & 0.393962 & 19.03086 & 27.58434 & 0.4122 \\
\hline At most 5 & 0.297767 & 13.43261 & 21.13162 & 0.4132 \\
\hline At most 6 & 0.166715 & 6.930410 & 14.26460 & 0.4974 \\
\hline At most 7 & 0.015507 & 0.593864 & 3.841466 & 0.4409 \\
\hline
\end{tabular}

Max-eigenvale test indicates 4 cointegrating eqn (s) at the 0.05 level. $*$ denotes rejection of the hypothesis at the 0.005 level. ** Mackinnon-Haug-Michelis (1999) p-values.

\subsubsection{Long Run Relationship}

As indicated by cointegration results, there exists a stable long run relationship among the variables in the investment model as well. The estimated long run normalised coefficients from the VECM are reported in Table 12.

Table 12: Cointegration coefficients from VECM

\begin{tabular}{lccc}
\hline \hline Regressor & Coefficient & Standard Error & T Ratio \\
\hline $\ln I N V$ & 1.000000 & & \\
$\ln P G D P$ & 0.784885 & $(0.08020)$ & {$[9.78622]^{*}$} \\
$\ln T P D$ & 0.309944 & $(0.08673)$ & {$[3.57386]^{*}$} \\
$\ln D S P$ & -0.085517 & $(0.05948)$ & {$[-1.73771]^{* *}$} \\
$\ln D S V$ & $(0.04119)$ & {$[4.96090] *$} \\
$\operatorname{lnOPN}$ & $(0.03963)$ & {$[8.57507]^{*}$} \\
$\ln I N F$ & 0.204336 & $(0.06187)$ & {$[-8.39779] *$} \\
$\ln E C R$ & -0.519546 & $(0.11339)$ & {$[-5.84142] *$} \\
\hline & -0.662331 &
\end{tabular}


As per the long run normalised coefficients, there is a clear positive and significant correlation between total public debt and investment in the long run, indicating the indirect effect of public debt on economic growth. Considering the fact that, it can be argued that the investment is one of the basic channels through which public debt can affect economic growth. There is rich empirical evidence, which relates to both Sri Lankan and global contexts to support this conclusion. (eg,. Akram 2017; Munir 2015; Chongo 2013; Hassan 2012). In contrast, debt service payments indicate a long run negative impact on investment, reflecting a marginal crowding out investment as it is significant at 10 per cent level. This implies that high debt servicing cost derived from the increased debt accumulation and high interest rates reduces the investment in the country. This conclusion is also consistent with a Sri Lankan study conducted by Akram (2017). However, it is observed that the overall impact of increasing public debt on investment seems to be favourable as the negative impact of crowding out investment is outweighed by the positive effect of total public debt on investment.

As expected, domestic savings and openness show a long run positive impact on investment with 5 per cent significant level. Openness measures the trade growth and therefore, more openness of an economy causes to increase the investment opportunities (Mhlaba 2017; Riffat 2015). Inflation, which is considered as a direct measure of monetary policy, affects economic growth, and exhibits a statistically significant negative correlation to the investment in the long run. This is supported by the findings of Atique (2012). Exchange rate also shows a significant negative impact on investment in the long run. This result is comparable with the conclusion made by Razzaque (2017). Per capita GDP has a significant impact on investment, suggesting that improving economic activity tends to further invest in the country.

Estimated ECT of the investment model is also significant and indicates a negative sign complying with the VECM conditions. This further confirms that long run relationships prevail among the variables.

\subsubsection{Results of VECM and Short Run Relationship}

The result of the error correction representation is reported in Table 13. Similar to the long run, it is also evidenced from the short run results that debt indicators such as total public debt and debt service payments have a significant influence on investments in the country. The estimates of Wald test also confirm that the short run association remained between the debt ratios and the investments (Table A4). Accordingly, two periods lagged total public debt positively affect investments, reflecting the combined positive effect of both domestic and foreign debt. On the other hand, one period lagged debt service payment shows a negative impact on investments, which is similar to the long run results. These results are consistent with the theories and some empirical evidence previously introduced. Inflation and exchange rate show a negative link to investments in the short run. These outcomes are consistent with the findings made by Mencinger (2014) and Razzaque (2017), respectively. However, openness 
indicates a negative correlation with investment in the short run, reflecting an adverse effect of large capital inflow and outflow gap. This is consistent with the findings made by Bibi et al (2012). Per capita GDP positively influences investment even in the short run.

Table 13: VECM regression results

\begin{tabular}{|c|c|c|c|c|}
\hline \multicolumn{5}{|c|}{ Dependent Variable: $\ln I N V$} \\
\hline & Coefficient & Standard Error & T Ratio & Probability \\
\hline$E C T * *$ & -1.63942 & 0.22654 & -7.23674 & 0.0000 \\
\hline $\ln I N V(-1) * *$ & 1.14331 & 0.18409 & 6.21033 & 0.0000 \\
\hline $\ln I N V(-2) * *$ & 0.33406 & 0.15242 & 2.19177 & 0.0404 \\
\hline $\ln T P D(-1)$ & -0.20851 & 0.37332 & -0.55853 & 0.5827 \\
\hline $\operatorname{lnTPD}(-2) * *$ & 0.63312 & 0.29672 & 2.13372 & 0.0454 \\
\hline $\ln D S P(-1) * *$ & -0.20674 & 0.08262 & 2.50222 & 0.0211 \\
\hline $\ln D S P(-2)$ & 0.10164 & 0.08503 & 1.19538 & 0.2459 \\
\hline $\operatorname{lnDSV}(-1)$ & 0.05768 & 0.10449 & 0.55198 & 0.5871 \\
\hline $\ln D S V(-2)$ & 0.07661 & 0.09672 & 0.79202 & 0.4376 \\
\hline $\operatorname{lnOPN}(-1) * *$ & -0.74371 & 0.18032 & -4.12430 & 0.0005 \\
\hline $\ln O P N(-2)$ & -0.08918 & 0.20329 & -0.43868 & 0.6656 \\
\hline $\ln I N F(-1)$ & -0.19542 & 0.30175 & -0.64762 & 0.5246 \\
\hline $\ln I N F(-2) * *$ & -0.64860 & 0.18607 & -3.48581 & 0.0023 \\
\hline $\ln E C R(-1)$ & 0.25374 & 0.41838 & 0.60648 & 0.5510 \\
\hline $\ln E C R(-2) * *$ & -0.77266 & 0.28361 & -2.72437 & 0.0131 \\
\hline $\ln P G D P(-1)$ & -0.00764 & 0.60617 & -0.01260 & 0.9901 \\
\hline $\ln P G D P(-2) * *$ & 2.49624 & 0.49470 & 5.04592 & 0.0001 \\
\hline Constant & -0.24419 & 0.07662 & -3.18677 & 0.0046 \\
\hline R-squared & 0.83051 & Mean de & t var & 0.0091 \\
\hline S.E. of regression & 0.05801 & S.D. de & var & 0.1036 \\
\hline Sum squared resid & 0.06730 & Akaike i & rion & -2.5509 \\
\hline Log likelihood & 66.4676 & Schwa & & -1.7752 \\
\hline F-statistic & 5.76479 & Hannan- & riter. & -2.2749 \\
\hline $\operatorname{Prob}(\mathrm{F} \text {-statistic })^{*}$ & 0.00016 & Durbin & stat & 1.9162 \\
\hline
\end{tabular}

Note: $* *$ and $*$ indicate significance at $5 \%$ level and $10 \%$ level, respectively. 


\subsection{Post estimation tests}

Major diagnostic tests were carried out to ensure the validity of estimated models. The respective results are tabulated in Table 14. The test for serial correlation (LM test) of both models found insignificant probabilities at 5 per cent level with no serial correlation null hypothesis in the residuals. This implies that the models are appropriate to give valid results. The Heteroscedasticity problem was also addressed by employing the Breusch Pagan-Godfrey technique. The corresponding results indicate that no heteroscedasticity problem in the models due to the failure of rejection of the null hypothesis of no heteroscedasticity at 5 per cent significant level. The normality tests were estimated to determine whether residuals are normally distributed with zero mean or not. The insignificant probabilities of Jarque-Bera test statistics affirm the normal distribution of residuals, suggesting the high validity of the regression models.

Table 14: Results of diagnostic tests

\begin{tabular}{|c|c|c|c|}
\hline Diagnostic Test & & Growth Model & $\begin{array}{c}\text { Investment } \\
\text { Model }\end{array}$ \\
\hline Breusch-Godfrey serial correlation LM test & & $\begin{array}{c}0.420860 \\
(0.5165)\end{array}$ & $\begin{array}{c}0.104052 \\
(0.7470)\end{array}$ \\
\hline Breush-Pagan-Godfrey heteroscedasticity & F- statistic & $\begin{array}{c}1.211554 \\
(0.3684)\end{array}$ & $\begin{array}{c}0.613530 \\
(0.8548)\end{array}$ \\
\hline Jarque-Bera normality test statistic & & $\begin{array}{c}1.032213 \\
(0.5968)\end{array}$ & $\begin{array}{c}3.945550 \\
(0.1391)\end{array}$ \\
\hline
\end{tabular}

Note: Probabilities of the test statistics are given in the Parenthesis.

The robustness of the estimated VECM model was also checked using two standard stability tests: CUSUM and CUSUM following the literature (Pegkas 2018). Accordingly, both CUSUM and CUSUM of Square graphs exhibited that their coefficients lie within the critical boundary with 5 per cent significant levels, reflecting the stability of the coefficients (Appendix Figures 1 and 2).

\section{Conclusion and policy recommendations}

The study investigated the impact of public debt on economic growth and investment in Sri Lanka covering the period from 1977 to 2017. Accordingly, two model specifications namely growth model and investment model were estimated applying Johansen Cointegration and the VECM technique specified under VAR model. The growth model examined the direct effect of public debt on economic growth, while the investment model explored its indirect impact on economic growth. 
The long run coefficients of the growth model found that both domestic and foreign public debt have a significant positive effect on economic growth in the long run. This implies that the public debt plays a significant role in generating economic growth of the country. The given argument is supported by similar results found in the investment model, which suggest that public debt has a significant positive effect on investment as well. The results convey that investment is a basic channel through which public debt influences economic growth in the long run. In contrast, debt service payments show a significant long run negative effect on both economic growth and investment, reflecting a crowding out investment in the economy. The VECM that captured the short run dynamics of economic growth also confirmed a short run association between public domestic debt and economic growth. At the same time, the investment model revealed a short run relationship between total public debt and investment. Reflecting a crowding out investment, debt service payments in the investment model also showed a significant negative effect on investment in the short run. Wald test results further confirmed above short run associations relating to both models.

This study mainly facilitates for policymakers to take their investment decisions effectively and efficiently with a prudential debt management in the county. Accordingly, the government should focus its attention on the potential contribution of public debt on economic growth and investments. That is, if Sri Lanka utilises its borrowings for productive investment purposes, it will enhance the investments and thereby economic growth in the country, particularly in the long run.

Parallel to this, it is also required to preserve a prudent debt management strategy in the country when financing government expenditure as higher accumulation of public debt, on the other hand, may have a negative impact on both economic growth and investment to some extent. Improved debt management strategy can reduce the interest cost and other fiscal risks including the rupee depreciation effect, which will offset the adverse impact of crowding out investment to some extent.

Moreover, introducing proactive policy measures is needed to broaden the tax base and thereby enhance the government's revenue targets to finance its budget deficit. This will facilitate the government to fully utilise all borrowed funds for capital development projects. The negative relationship between population growth and economic growth suggests the necessity of improving effectiveness of population growth by reducing its growth and increasing human capital. It is also a responsibility of policy makers to manage public debt closely coordinated with monetary and macroeconomic policies as inflation and exchange rate are negatively correlated to investment.

Future researchers can expand their studies by examining the impact of public debt considering the structural breaks as pre-independence and post-independence. Also, it is important to measure the threshold level of public debt for Sri Lanka. Moreover, future research may investigate the different channels through which public debt impacts economic growth. 


\section{References}

Akram, N., (2010/2011), "Impact of public debt on the economic growth of Pakistan", The Pakistan Development Review, No. 50 (4), pp.599-615.

Akram, N., (2015), "Is public debt hindering economic growth of the Philippines? International Journal of Social Economics, Vol.42, Issue: 3, pp.202-221.

Akram, N., (2016), "Public Debt and Pro-poor Economic Growth-Evidence from South Asia, "Journal of Economic Research, Vol.29:1, pp.746-757.

Akram, N., (2017), "Role of public debt in economic growth of Sri Lanka: an ARDL Approach", Pakistan Journal of Applied Economics, Vol.27, No.2, pp. 189-212.

Atique, R and Malik, K., (2012), "Impact of domestic and external debt on the economic growth of Pakistan”, World Applied Sciences Journal 20(1), pp.120-129.

Al-Refai, M. F., (2015), "Debt and economic growth in developing countries: Jordan as a case study", International Journal of Economics and Finance, Vol. 7, No.3, pp.134-143.

Aslam, A. L. M., (2016), "Budget deficit and economic growth in Sri Lanka: An econometric dynamic analysis, World scientific news, WSN 46, pp. 176-188

Asari, F. A. H., Baharuddin, N. S., Jusoh, N., Mohamad, Z., Shamsudin, N and Jusoff, K., (2011), "A vector error correction model (VECM) approach in explaining the relationship between interest rate and inflation towards exchange rate volatility in Malaysia", World Applied Sciences Journal, No.12, pp.49-56.

Attapattu, A. M. C. P and Padmasiri, H. M. N., (2018), "Long run association between public debt and economic growth in Sri Lanka", Scientific Research Publishing, No.9, pp.775789.

Bernheim, B. D., (1989), "A neoclassical perspective on budget deficits", Journal of Economic Perspectives, Vol.3, No.2, pp. 55-72.

Bibi, s., Khan, U. A. and Bibi, A., (2020), “Determinants of investment in Pakistan”, Academic Research International, 2(2), pp. 517-524.

Bilan, I., (2016), "Overview of the main theories on the economic effects of public indebtedness”, EIRP Proceedings, Vol. 11, pp. 1-9

Central Bank Of Sri Lanka, Annual Reports (1978-2017).

Clements, b., Bhattacharya, r., and Nguyen, T. Q., (2003), "External debt, public investment, and growth in low-income countries", IMF Working Paper, No. WP/03/249.

Chongo, B.M., (2013), “An econometric analysis of the impact of public debt on economic growth: The case of Zambia”, Master Thesis, University of Zambia. 
Coomaraswamy, I., (2017), "Revenue Based Fiscal Consolidation towards Sustainable Growth, Public Speech at the 21 st Annual Tax Oration, Central Bank of Sri Lanka.

Deshappriya, N. P. R., (2012), "Debt and fiscal sustainability in Sri Lanka”, International Journal of Scientific and Research Publications, Vol.2, Issue 3.

Egbetunde, T., (2012), "Public debt and economic growth in Nigeria: Evidence from Granger Causality", American journal of Economics, No, 2(6), pp.101-106.

Ekanayake, D. G. D. I., (2011), “Assessing government debt sustainability in Sri Lanka”, Central Bank of Sri Lanka.

Fonseka, A. T. and Ranasinghe, S. S., (2008), "Sustainability of Sri Lanka’s Public Debt", Sri Lankan Journal of Management, Vol.13, No.1\&2, pp 185-216.

Greenidge, K., Roland, C., Thomas, C and Darkes, L., (2012), “Threshold effects of sovereign debt: Evidence from the Caribbean," IMF Working Paper No. 12/157.

Hafiz, A., (2004), "Pro-poor growth and policies-The Asian Experiences", Asia Pacific Regional Programme on the Macroeconomics of Poverty Reduction, United Nations Development Programme.

Hassan, MD. H. and Akhter, T., (2012), "Public debt burden and economic growth of Bangladesh: A VAR approach", SSRN Electronic Journal, ResearchGate.

Hjalmarsson, E. and Osterholm, P., (2007), "Testing for cointegration using the Johanson methodology when variables are near integrated", IMF Working Paper, WP/07/141.

Kobayashi, K., (2015), "Public debt overhang and economic growth, Public Policy Review, Vol.11, No.2. Japan.

Kobey, G. L., (2016), "Effect of public debt on economic growth in Kenya", Master Theses, University of Nairobi.

Kumara, H and Cooray, N. S., (2013), "Public debt and economic growth in Sri Lanka: Is there any threshold level for public debt"? Economics and Management Series EMS-2013-22, International University of Japan.

Mencinger, J., Aristovnik and Verbic., (2014), "The impact of growing public debt on economic growth in the European Union”, Working Paper No.80, pp.1-25.

Mhlaba, N., and Phiri, A., (2017), "Is public debt harmful towards economic growth? New evidence from South Africa”, MPRA paper No.83157, Nelson Mandela University.

Ministry of Finance of Sri Lanka, Annual Reports (2014-2017).

Mohanty, A. R and Mishra, B.R., (2016), "Impact of public debt on economic growth: Evidence from Indian States”, The XIMB Journal of Management, Vol, 13 (2), pp.1-21.

Munir, N. R. K., (2015), "Exploring the channels and impact of debt on economic growth in South Asia", Munich Personal RePEc Archive (MPRA) Paper, No. 66830. 
Nastansky, A., Mehnert, A and Strohe, H. G., (2014), "A vector error correction model for the relationship between public debt and inflation in Germany".

Ngugi, W. N., (2016), "Effect of public debt on economic growth in Kenya, Master Thesis, Kenyata University.

Ntshakala, P. L., (2014), "Effects of public debt on economic growth in Swaziland", International Journal of Business and Commerce, Vol.5, No.01, pp. 01-24.

Owusu, N. V and Erickson, C., (2016), "Public debt and economic growth in Ghana", African Development Review, Vol. 28, No. 1, pp.116-126.

Panizza, U., Andea, F and Presbitero., (2014), "Public debt and economic growth: Is there a causal effect?” Journal of Macroeconomics (41), pp.21-41.

Pegkas, P., (2018), “The effect of government debt and other determinants on economic growth: The Greek experience", Journal of Economies (MDPI), University of Thessaly.

Pesaran, H.M., Shin, Y and Smith, R.J., (2001), "Bound testing Approches to analysis of level relationship", Journal of Applied Economics, 16(3), pp.174-189.

Razzaque, M. A., Bidisha, S. H and Khondker, B. H., (2017), "Exchange rate and economic growth: An empirical assessment for Bangladesh, Journal of South Asian Development, 12(I), pp.42-64.

Saifuddin, MD., (2016), "Public debt and economic growth: Evidence from Bangladesh", Global Journal of Management and Business Research: B Economics and Commerce, Vol. 16, Issue 5, Version 1.

Sanderatne, N., (2011), "The growing debt burden: Imperative for economic development" The Sunday Time Economic Analysis, http://www.sundaytimes.lk/ 110116/Columns/eco.html.

Sargent, T. J and Ljungqvist, L., (2000), "Recursive macroeconomic theory", Second edition, Stockholm School of Economics and New York University.

Saeed, S and Islam, T. U., (2016), "Public debt and economic growth incorporating endogeneity and nonlinearity", $S^{3} H$ Working Paper Series, National University of Science and Technology, Pakistan.

Siddiqui, R \& Malik, A., (2001), "Debt and economic growth in South Asia", Pakistan Development Review, No. 40:4 (II), pp. 677-688.

Silva, N. L. C., Silva, N. K. L and perera, P. R. M. R., (2015), "Effect of government debt on gross domestic production evidence from Sri Lanka", $2^{\text {nd }}$ International Conference for Accounting Researchers and Educators, University of Kelaniya.

Solow, R. M., (1956), “A contribution to the theory of economic growth", The Quarterly Journal of Economics, Vol. 70, No.1, pp. 65-95. 
SOLOW, R. M., (1956), "A contribution to the theory of economic growth", The Quarterly Journal of Economics, Vol. 70, No.1, pp. 65-95.

SRI LANKA DEVELOPMENT UPDATE, (2017), "Creating opportunities and managing risks for sustained growth", The World Bank.

SRI LANKA DEVELOPMENT UPDATE, (2018), "More and better jobs for an upper middle- income country", The World Bank.

SUHARSONO, A., AZIZA, A \& PRAMESTI, W., (2017), "Comparison of vector autoregressive (VAR) and vector error correction models (VECM) for index of ASEAN stock price", International Conference and Workshop on Mathematical Analysis and its Applications (ICWOMAA).

UKESSAYS, “Theoriesofgrowthanddebt”,(2015),https://www.ukessays.com/essays/econo mics/literature-review-of-growth-and-debt-theories-economics-essay.php.

WEERASINGHE, I. M. S \& MADHUWANTHI, L. A. P., (2010), "Relationship between Domestic debt and gross domestic product in Sri Lanka: A time series analysis", Master Thesis, University of Sri Jayewardenepura.

WIBOWO, M. G., (2017), "Public debt and economic growth in Southeast Asia", Jurnal IImu Ekonomi, Vol 6(I), pp. 177-188.

YOSHINO, N., MIZOGUCHI, T., \& TAGHIZADEH, H. F., (2015), “Optimal fiscal policy rule for achieving fiscal sustainability: A Japanese Case Study”, ADBI Working Paper.

ZEAUD, H. A., (2014), "Public debt and economic growth: an empirical assessment", European Scientific Journal, Vol.10, No.4, pp.148-158. 


\section{Appendices}

Table A1: Descriptive statistics of all log variables

\begin{tabular}{lcccccccc}
\hline Variable & Mean & Median & Maximum & Minimum & Std. Dev. & Skewness & Kurtosis & Obs.v. \\
\hline $\ln P G D P$ & 10.75 & 10.78 & 13.33 & 7.87 & 1.62 & -0.02 & 1.88 & 41 \\
$\ln I N V_{p}$ & 3.06 & 3.08 & 3.50 & 2.23 & 0.22 & -1.12 & 6.04 & 41 \\
$\ln I N V_{g}$ & 1.52 & 1.58 & 2.14 & 1.01 & 0.30 & -0.21 & 1.97 & 41 \\
$\ln P D D$ & 3.79 & 3.77 & 4.09 & 3.51 & 0.13 & 0.49 & 2.81 & 41 \\
$\ln P F D$ & 3.71 & 3.66 & 4.12 & 3.37 & 0.22 & 0.23 & 1.78 & 41 \\
$\ln D S P$ & 2.34 & 2.42 & 2.94 & 1.64 & 0.32 & -0.60 & 2.88 & 41 \\
$\ln O P N$ & 4.02 & 4.67 & 4.34 & 3.59 & 0.23 & -0.69 & 2.22 & 41 \\
$\ln P O P$ & 0.19 & 0.23 & 0.85 & -1.42 & 0.37 & -2.02 & 10.48 & 41 \\
$\ln I N V$ & 3.27 & 3.25 & 3.67 & 2.67 & 0.19 & -0.38 & 4.31 & 41 \\
$\ln T P D$ & 4.44 & 4.46 & 4.69 & 4.21 & 0.14 & -0.14 & 1.76 & 41 \\
$\ln D S V$ & 2.77 & 2.77 & 3.38 & 2.42 & 0.22 & 0.70 & 3.64 & 41 \\
$\ln I N F$ & 2.86 & 3.03 & 4.78 & 0.06 & 1.37 & -0.29 & 1.98 & 41 \\
$\ln E C R$ & 4.01 & 4.08 & 5.02 & 2.18 & 0.76 & -0.49 & 2.16 & 41 \\
\hline \hline
\end{tabular}

Table A2: Breakpoint unit root analysis for all log variables

\begin{tabular}{|c|c|c|}
\hline & \multicolumn{2}{|c|}{ Augmented Dickey Fuller (ADF) } \\
\hline & Level & First difference \\
\hline $\ln P G D P$ & -4.652072 & $-6.141737 *$ \\
\hline $\ln I N V$ & -4.790383 & $-7.159949 *$ \\
\hline $\ln I N V_{g}$ & -4.515532 & $-9.149156^{*}$ \\
\hline $\ln I N V_{p}$ & -4.722472 & $-6.123547^{*}$ \\
\hline $\ln P D D$ & -4.186910 & $-7.649906^{*}$ \\
\hline $\ln P F D$ & -4.565739 & $-8.937415^{*}$ \\
\hline $\operatorname{lnTPD}$ & -3.841406 & $-7.928893 *$ \\
\hline $\ln D S P$ & -3.804723 & $-10.86972^{*}$ \\
\hline $\operatorname{lnOPN}$ & $-5.983520^{*}$ & $-9.235561 *$ \\
\hline $\ln D S V$ & -4.536860 & $-8.646166^{*}$ \\
\hline $\ln P O P$ & $-8.993975^{*}$ & $-15.16845^{*}$ \\
\hline $\ln I N F$ & $-5.449537 *$ & $-13.46811 *$ \\
\hline $\ln E C R$ & $-7.296838^{*}$ & $-15.50774^{*}$ \\
\hline
\end{tabular}




\begin{tabular}{ccc}
\hline & Critical Values & \\
\hline $1 \%$ Critical Value & -5.347598 & -5.347598 \\
$5 \%$ Critical Value & -4.859812 & -4.859812 \\
$10 \%$ Critical Value & -4.607324 & -4.607324 \\
\hline$*$ indicates significance at $1 \%, 5 \%$ and $10 \%$. &
\end{tabular}

Table A3: Results of the Wald Test -growth model

\begin{tabular}{|c|c|c|c|c|c|c|c|c|c|}
\hline Variable & $L n P G D P$ & $\operatorname{LnINV}_{g}$ & $\operatorname{LnINV}_{p}$ & $L n P D D$ & $L n P F D$ & $\operatorname{LnDSP}$ & $\operatorname{LnOPN}$ & $\operatorname{LnPOP}$ & $E C T^{*}$ \\
\hline $\ln P G D P$ & & $\begin{array}{l}4.3782 \\
(0.112)\end{array}$ & $\begin{array}{c}4.5854 \\
(0.100)^{* *}\end{array}$ & $\begin{array}{c}6.0723 \\
(0.048)^{*}\end{array}$ & $\begin{array}{l}0.6226 \\
(0.732)\end{array}$ & $\begin{array}{l}3.0804 \\
(0.214)\end{array}$ & $\begin{array}{l}0.7150 \\
(0.699)\end{array}$ & $\begin{array}{l}2.4564 \\
(0.292)\end{array}$ & $\begin{array}{l}-0.0081 \\
(0.038)^{*}\end{array}$ \\
\hline $\ln I N V_{g}$ & $\begin{array}{l}2.4388 \\
(0.295)\end{array}$ & & $\begin{array}{l}0.6046 \\
(0.739)\end{array}$ & $\begin{array}{l}4.3324 \\
(0.114)\end{array}$ & $\begin{array}{c}4.9668 \\
(0.084)^{* *}\end{array}$ & $\begin{array}{l}0.3840 \\
(0.825)\end{array}$ & $\begin{array}{l}0.1889 \\
(0.909)\end{array}$ & $\begin{array}{l}2.0602 \\
(0.357)\end{array}$ & $\begin{array}{r}-0.0011 \\
(0.931)\end{array}$ \\
\hline $\ln I N V_{p}$ & $\begin{array}{c}7.1323 \\
(0.028)^{*}\end{array}$ & $\begin{array}{l}0.0302 \\
(0.985)\end{array}$ & & $\begin{array}{l}3.1064 \\
(0.212)\end{array}$ & $\begin{array}{l}0.2663 \\
(0.875)\end{array}$ & $\begin{array}{l}0.1321 \\
(0.936)\end{array}$ & $\begin{array}{l}2.2946 \\
(0.318)\end{array}$ & $\begin{array}{l}0.3250 \\
(0.850)\end{array}$ & $\begin{array}{r}-0.0021 \\
(0.840)\end{array}$ \\
\hline $\ln P D D$ & $\begin{array}{l}0.6836 \\
(0.711)\end{array}$ & $\begin{array}{l}0.4265 \\
(0.808)\end{array}$ & $\begin{array}{l}0.6364 \\
(0.728)\end{array}$ & & $\begin{array}{l}3.0969 \\
(0.212)\end{array}$ & $\begin{array}{l}2.4622 \\
(0.292)\end{array}$ & $\begin{array}{l}2.8982 \\
(0.234)\end{array}$ & $\begin{array}{c}7.7395 \\
(0.021)^{*}\end{array}$ & $\begin{array}{l}0.0109 \\
(0.068)\end{array}$ \\
\hline $\ln P F D$ & $\begin{array}{c}8.4702 \\
(0.014)^{*}\end{array}$ & $\begin{array}{c}6.7938 \\
(0.034)^{*}\end{array}$ & $\begin{array}{c}7.5802 \\
(0.022)^{*}\end{array}$ & $\begin{array}{c}7.0053 \\
(0.030)^{*}\end{array}$ & & $\begin{array}{c}6.2507 \\
(0.044) *\end{array}$ & $\begin{array}{c}6.4352 \\
(0.040)^{*}\end{array}$ & $\begin{array}{l}17.1771 \\
(0.000)^{*}\end{array}$ & $\begin{array}{c}0.0176 \\
(0.004)^{*}\end{array}$ \\
\hline $\ln D S P$ & $\begin{array}{c}8.4666 \\
(0.014)^{*}\end{array}$ & $\begin{array}{l}0.3499 \\
(0.839)\end{array}$ & $\begin{array}{c}9.0048 \\
(0.011)^{*}\end{array}$ & $\begin{array}{l}1.9749 \\
(0.372)\end{array}$ & $\begin{array}{c}5.1048 \\
(0.078)^{* *}\end{array}$ & & $\begin{array}{l}3.8937 \\
(0.142)\end{array}$ & $\begin{array}{c}5.0390 \\
(0.080)^{*} \\
*\end{array}$ & $\begin{array}{c}-0.0182 \\
(0.109)\end{array}$ \\
\hline $\ln O P N$ & $\begin{array}{c}6.9483 \\
(0.031)^{*}\end{array}$ & $\begin{array}{l}1.8460 \\
(0.397)\end{array}$ & $\begin{array}{l}2.4412 \\
(0.295)\end{array}$ & $\begin{array}{l}0.9254 \\
(0.629)\end{array}$ & $\begin{array}{c}(0.7657) \\
(0.082)^{* *}\end{array}$ & $\begin{array}{l}4.2272 \\
(0.121)\end{array}$ & & $\begin{array}{l}0.2559 \\
(0.879)\end{array}$ & $\begin{array}{l}0.0014 \\
(0.808)\end{array}$ \\
\hline $\ln P O P$ & $\begin{array}{l}0.4629 \\
(0.793)\end{array}$ & $\begin{array}{l}1.0638 \\
(0.588)\end{array}$ & $\begin{array}{l}2.5173 \\
(0.284)\end{array}$ & $\begin{array}{l}1.6921 \\
(0.429)\end{array}$ & $\begin{array}{l}0.0402 \\
(0.980)\end{array}$ & $\begin{array}{l}4.5558 \\
(0.102)\end{array}$ & $\begin{array}{l}1.6568 \\
(0.437)\end{array}$ & & $\begin{array}{l}0.0010 \\
(0.972)\end{array}$ \\
\hline
\end{tabular}

Note: probabilities are in the parentheses. ${ }^{*}$ and ${ }^{* *}$ indicate significance at $5 \%$ and $10 \%$, respectively. 
Table A4: Results of the Wald Test-investment model

\begin{tabular}{|c|c|c|c|c|c|c|c|c|c|}
\hline Variable & $\operatorname{LnINV}$ & $\operatorname{LnPGDP_{g}}$ & LnTPD & $\operatorname{LnDSP}$ & LnDSV & $\operatorname{LnOPN}$ & LnINF & $\operatorname{LnEXR}$ & $E C T^{*}$ \\
\hline $\operatorname{lnINV}$ & & $\begin{array}{l}27.4737 \\
(0.000)^{*}\end{array}$ & $\begin{array}{c}5.8444 \\
(0.054)^{* *}\end{array}$ & $\begin{array}{c}6.3752 \\
(0.041)^{*}\end{array}$ & $\begin{array}{l}0.7749 \\
(0.679)\end{array}$ & $\begin{array}{c}19.499 \\
(0.000)^{*}\end{array}$ & $\begin{array}{c}13.397 \\
(0.001)^{*}\end{array}$ & $\begin{array}{l}8.3307 \\
(0.016)^{*}\end{array}$ & $\begin{array}{l}-1.6394 \\
(0.000)^{*}\end{array}$ \\
\hline $\ln P G D P$ & $\begin{array}{c}6.5316 \\
(0.038)^{*}\end{array}$ & & $\begin{array}{l}1.8564 \\
(0.395)\end{array}$ & $\begin{array}{l}3.5038 \\
(0.173)\end{array}$ & $\begin{array}{l}1.3401 \\
(0.512)\end{array}$ & $\begin{array}{l}2.3890 \\
(0.302)\end{array}$ & $\begin{array}{l}2.6653 \\
(0.264)\end{array}$ & $\begin{array}{l}2.7157 \\
(0.257)\end{array}$ & $\begin{array}{r}-0.1350 \\
(0.509)\end{array}$ \\
\hline $\ln T P D$ & $\begin{array}{l}3.6325 \\
(0.162)\end{array}$ & $\begin{array}{l}1.6654 \\
(0.434)\end{array}$ & & $\begin{array}{l}2.9297 \\
(0.231)\end{array}$ & $\begin{array}{l}0.0115 \\
(0.994)\end{array}$ & $\begin{array}{l}2.5318 \\
(0.282)\end{array}$ & $\begin{array}{l}1.2444 \\
(0.537)\end{array}$ & $\begin{array}{l}3.3017 \\
(0.192)\end{array}$ & $\begin{array}{c}0.1828 \\
(0.5464)\end{array}$ \\
\hline $\ln D S P$ & $\begin{array}{l}1.8204 \\
(0.402)\end{array}$ & $\begin{array}{l}0.7507 \\
(0.687)\end{array}$ & $\begin{array}{l}2.2707 \\
(0.321)\end{array}$ & & & $\begin{array}{l}0.3608 \\
(0.834)\end{array}$ & $\begin{array}{l}2.7414 \\
(0.254)\end{array}$ & $\begin{array}{l}1.8129 \\
(0.404)\end{array}$ & $\begin{array}{l}0.2619 \\
(0.652)\end{array}$ \\
\hline $\ln D S V$ & $\begin{array}{l}0.6263 \\
(0.731)\end{array}$ & $\begin{array}{l}1.1408 \\
(0.565)\end{array}$ & $\begin{array}{l}0.0769 \\
(0.962)\end{array}$ & $\begin{array}{l}2.1384 \\
(0.343)\end{array}$ & & $\begin{array}{l}0.4515 \\
(0.798)\end{array}$ & $\begin{array}{l}1.0339 \\
(0.596)\end{array}$ & $\begin{array}{l}1.1139 \\
(0.572)\end{array}$ & $\begin{array}{l}1.1950 \\
(0.006)\end{array}$ \\
\hline $\ln O P N$ & $\begin{array}{l}8.3094 \\
(0.016)^{*}\end{array}$ & $\begin{array}{l}1.2509 \\
(0.535)\end{array}$ & $\begin{array}{l}2.2458 \\
(0.325)\end{array}$ & $\begin{array}{c}10.189 \\
(0.002)^{*}\end{array}$ & $\begin{array}{l}2.5543 \\
(0.279)\end{array}$ & & $\begin{array}{c}6.1544 \\
(0.046)^{*}\end{array}$ & $\begin{array}{l}0.1957 \\
(0.907)\end{array}$ & $\begin{array}{l}-0.7042 \\
(0.007)^{*}\end{array}$ \\
\hline $\operatorname{lnINF}$ & $\begin{array}{l}1.3429 \\
(0.511)\end{array}$ & $\begin{array}{l}0.0815 \\
(0.960)\end{array}$ & $\begin{array}{l}0.4858 \\
(0.784)\end{array}$ & $\begin{array}{l}1.5036 \\
(0.471)\end{array}$ & $\begin{array}{l}0.5778 \\
(0.749)\end{array}$ & $\begin{array}{l}1.5979 \\
(0.449)\end{array}$ & & $\begin{array}{l}0.6372 \\
(0.727)\end{array}$ & $\begin{array}{r}-0.1379 \\
(0.559)\end{array}$ \\
\hline $\ln E X R$ & $\begin{array}{l}1.0972 \\
(0.578)\end{array}$ & $\begin{array}{l}0.6554 \\
(0.721)\end{array}$ & $\begin{array}{l}0.1196 \\
(0.942)\end{array}$ & $\begin{array}{l}1.2289 \\
(0.541)\end{array}$ & $\begin{array}{l}0.0557 \\
(0.972)\end{array}$ & $\begin{array}{l}9.9179 \\
(0.007)^{*}\end{array}$ & $\begin{array}{l}1.8809 \\
(0.394)\end{array}$ & & $\begin{array}{l}0.1203 \\
(0.478)\end{array}$ \\
\hline
\end{tabular}

Note: probabilities are in the parentheses. ${ }^{*}$ and ${ }^{* *}$ indicate significance at $5 \%$ and $10 \%$, respectively.

Figure A1: Results of the stability tests of recursive residuals - growth model

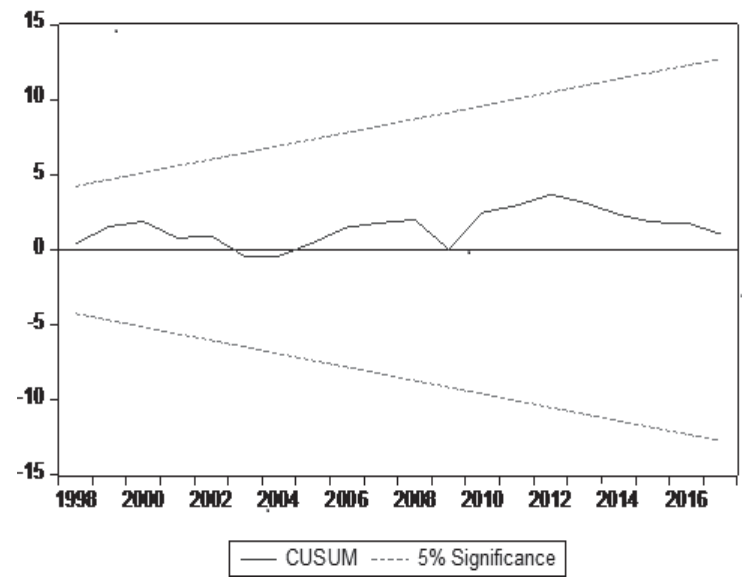




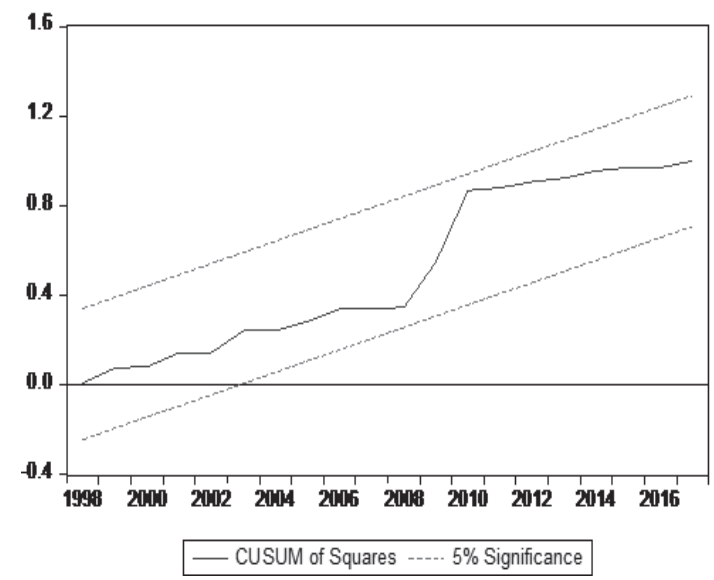

Figure A2: Results of the stability tests of recursive residuals - investment model
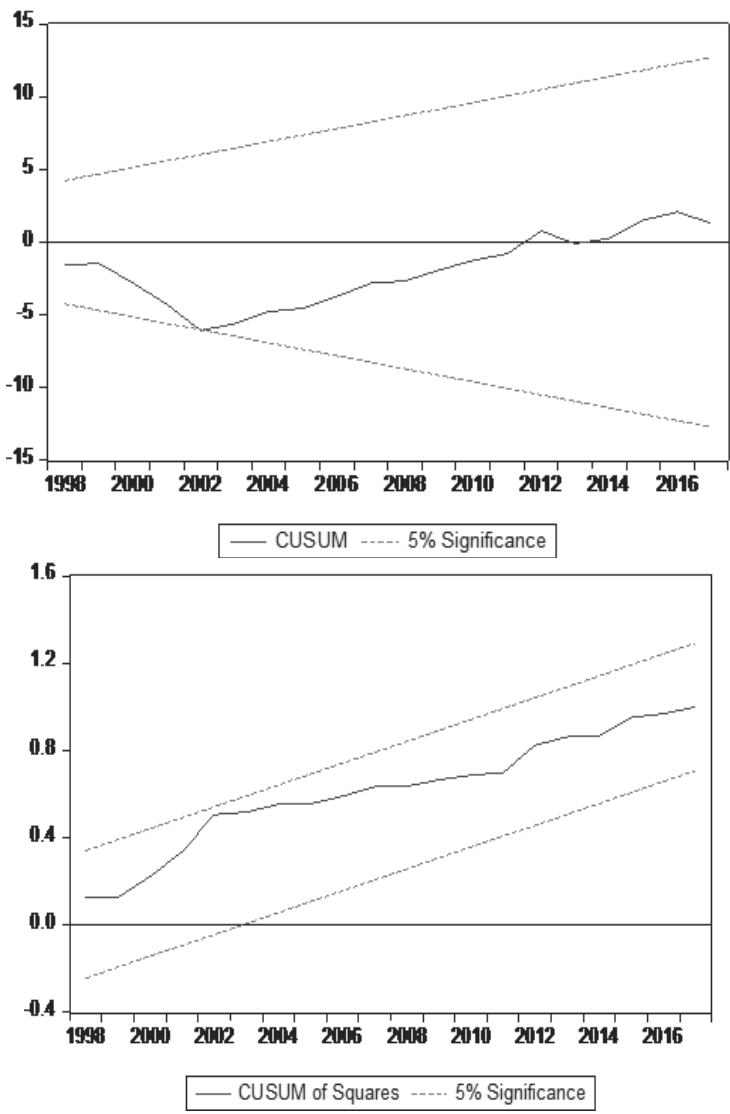